\title{
Solving the Dilemma of Congenital and Pathological Breast Asymmetry Using Modified Supine Oblique Sitting Marking Technique
}

\author{
MOHAMED AHMED AMIN SALEH, M.D., M.R.C.S.1; MOHAMED ABDELMOHSEN GHANEM, M.D.1; \\ REDA ABDELTAWAB, M.D.2; MOHAMED ELSHENAWY, M.D.2; MAHMOUD ABDELBAKY MAHMOUD, \\ M.D.2; MOHAMED SABRAY, M.D. 3; HANY ABDEAZIZ, M.D.3; AHMED HASSAN SOLIMAN, M.D.4; \\ NEVIN SHALABI, M.D.4; NAFISSA ELBADAWY, M.D. ${ }^{\mathbf{4}}$ and FATEN GHAAL, M.D. 5
}

The Departments of Plastic, Reconstruction Maxillofacial Surgeries \& Burn Management ${ }^{1}$, General Surgery ${ }^{2}$, Oncology ${ }^{3}$, Radiology ${ }^{4}$, Pathology ${ }^{5}$, Faculty of Medicine, Ain Shams University, Cairo, Egypt

\begin{abstract}
Background: The female breast is one of the most attractive aesthetic areas in female anatomy. The size, shape, and symmetry of the breasts can have a dramatic effect on the women's well-being, poor self-esteem, altered self-image, and other psychological effects. All surgical techniques was done based in the presurgical marking. However it is of little value if symmetry procedure will be done in other breast.

Material and Methods: We retrospectively reviewed 41 patients admitted to our multi-disciplinary team breast clinic in Ain Shams University Hospital, between July 2015 and September 2019. Patients' age ranged from 14 to 63 years. Congenital and pathological breast asymmetries were included e.g.: Chronic granulomatous mastitis, burns, and tumors of the breast (benign and malignant masses). Physiological breast asymmetry were excluded from the study.
\end{abstract}

Patients were operated upon using the modified SOS marking technique and followed-up for a mean of 13.24 months post-operatively (range 3-30 months). All patients were photographed before and after the surgery. Post-operative photographs of these patients were examined by five plastic surgeons ( 3 men and 2 woman). We compared both breasts using a 5 point subscale consisting of volume, contour, placement of the breast mound, scar and the inframammary fold and all patients were asked to complete a satisfaction questionnaire based on the Harvard scale.

Conclusion: It is a novel marking technique solved the dilemma of changing the pre-operative plane according to the intraoperative judgment and altering the amount of tissue to be excised or reconstructed in patients suffering from congenital and pathological breast asymmetry. It is technical easy to learn, reliable with satisfactory aesthetic outcome especial in congenital asymmetries, with acceptable complication rate.

Key Words: Breast asymmetry - Poland syndrome - Breast conservative treatment - Breast marking technique - Breast reconstruction - Aesthetic breast evaluation - Oncoplasty.

\section{INTRODUCTION}

Breast asymmetry present an aesthetic challenge to plastic surgeons as it is a symbol of female beauty; thus congenital and pathological breast conditions affect women lives to a great extent. Physiological asymmetry exist in normal female breasts. However, different cultures, the modern beauty parameters led women to look for perfection.

Nahai classified breast asymmetries into three groups: (1) Primary (congenital) breast asymmetry as Poland's Syndrome (PS) (2) Secondary (developmental) breast asymmetry (3) Patients with tertiary (acquired) breast asymmetry [1].

Improving the body image and breast symmetry is associated with better quality of life. To get good patient satisfaction, pre-operative examination and planning are considered main predictors of the aesthetic outcome. However clearly discussing with patient to achieve perfect symmetry is almost impossible and that it may take several procedures to achieve the goal [2-6].

Contra lateral symmetry following oncoplastic breast conservation is limited regarding patient decision-making and a systematic analysis of patients' views regarding this topic is lacking [7-12]. Smeele et al., 2019 ran an interview study to explore the factors involved in patient decision making about contralateral reduction mammoplasty [13].

All the surgical techniques described in the literature is based on the presurgical marking [1423]. However it is of little value if immediate symmetry carried on the contralateral breast and the 
amount of breast tissue to be excised is judged or altered according to the intraoperative findings as in; oncoplastic procedures, recurrent multiple fibro adenoma, juvenile hypertrophy of the breast, application of breast implant which chosen according to the intraoperative assessment as in Poland syndrome, nipple areola sparing mastectomy (NASM), Skin Sparing Mastectomy (SSM), and reconstruction with autologous tissue.

The aim of the study is to present our technique solving the dilemma of breast marking for managing congenital and pathological breast asymmetry.

\section{PATIENTS AND METHODS}

It is a cohort retrospective study included 41 patients with congenital and pathological breast conditions offered immediate contralateral mastopexy or reduction mammoplasty as well. It was done between June 2015 and June 2019 in Ain Shams University Hospitals, Cairo, Egypt "The Breast multidisciplinary teams MDT". Patients age ranged from 14 to 63 years (mean 39.36 years). Informed consent was obtained for all patients to be include in any study and for medical photography documentation as well.

Demographic, oncologic, operative, and photographic data were obtained for each patient. Patients were followed at 3, 6 and 12 months postoperatively (range 3-30 months). Criteria for inclusion were a complete demographic and oncologic history and photographic follow-up of at least twelve months (minimum 12 months, max 29 months). The variables include: Age, BMI, smoking, hypertension, diabetes, post-mastectomy radiation, adjuvant chemotherapy, and history of unilateral reconstruction or other breast procedures. See (Table 1).

Pre-operative assessment, medical and surgical plane was done by the breast MDT. In the present study, the modified SOS procedure was done to treat the pathology and achieve symmetry in the contralateral side. If there is a plan for radiotherapy, the symmetry procedure was delayed for at least 9 months. Patients were subdivided into three groups [24,25]. (1) Primary (congenital) breast asymmetry caused by Poland's Syndrome (PS) (2) Secondary (developmental) breast asymmetry caused by unilateral breast hypertrophy, and (3) Tertiary (acquired) breast asymmetry caused by burns, granulomatous mastitis, and we added in our study the benign: Recurrent fibro adenoma and malignant breast tumors and post mastectomy reconstruction as well. See (Table 2).
Tumor excision procedures was done by the two breast surgeons and reconstruction were performed by the two plastic surgeons. Post-operative photographs were assessed by 5 plastic surgeons ( 3 men and 2 woman). We used the same method previously described by Visser et al., [26]. Pre and post-operative standardized photographs of the breast area was done using a wide-angled digital camera. The breast region included the shoulder region level and the level of the umbilicus. Patients are were instructed to place their hands beside their body touching their buttocks and with a uniform background. 4 different views were taken to each patient: Frontal view, lateral and with an angle of 45 degrees between frontal and lateral views. Assessment was done as regard the breast volume, shape, symmetry, scars, and nipple areola complex. For each of these items a 5-point Likert scale is used for scoring. This scale ranges from "very dissatisfied," "dissatisfied," "neutral," "satisfied," to "very satisfied".

Patients were asked to complete a satisfaction questionnaire based on the Harvard scale, introduced by Jay Harris in 1979. It classifies the overall aesthetic results in four categories from excellent, good, and fair to poor [27-29]. See (Table 3).

Post-operative complications such as prolonged pain, hematoma, seroma, infection, flap necrosis, compromised nipple and areola complex vascularity, altered nipple and areola sensation, hypertrophic scar formation and secondary symmetry procedure were recorded. Informed consent was obtained from all patients included in the study.

\section{Technique used:}

In the modified SOS technique, the patient is marked pre-operatively as originally described by Fahmy et al., 2006 [30] and the epsilateral breast is treated as shown in (Table 2) and the marking is repeated while the patient is under general anesthesia.

While the patient is under general anesthesia, surgical stables were applied in the epsilateral breast e.g.: After tumor excision and before changing patient's position. The sitting position is adopted to mark the midline, the midclavicular point, and the breast meridian. It is marked as a straight line joining the midclavicular point to the current nippleareola complex extending down to the inframammary fold.

The supine position is used to mark the inframammary fold incision and the medial limit of the vertical markings. The inframammary fold is 
marked, with a very gentle pressure on the breast mound, the breast will naturally fall laterally. A straight line is drawn joining the superior limit of the vertical limbs to the meridian. This will indicate the medial limb of the vertical limbs.

The oblique position is taken to mark the lateral limb of the vertical markings. The patient is marked in the left and right oblique positions. In the left oblique position, the right breast will naturally adopt a medial position. A straight line is marked joining the superior limit of the vertical limb to the meridian. This marks the lateral limb of the right breast. The same is done for the other side.

Finally, the patient is returned to the sitting position. The medial and lateral vertical limbs are measured at a length of $7 \mathrm{~cm}$ from the superior limit of the vertical limbs. The two vertical limbs are then joined to the medial and lateral ends of the inframammary fold marking. See Fig. (1).

Table (1): Patient's data summary.

\begin{tabular}{|c|c|c|c|c|c|c|c|c|c|}
\hline \# & Etiology of asymmetry & Age & $\begin{array}{c}\text { No. of } \\
\text { operations }\end{array}$ & $\begin{array}{c}\text { Follow-up } \\
\text { (months) }\end{array}$ & DM & Smoking & Hypertension & RT & $\begin{array}{l}\text { Chemo } \\
\text { therapy }\end{array}$ \\
\hline 1 & Poland S & 20 & 2 & 19 & No & No & No & No & No \\
\hline 2 & Infection & 42 & 3 & 12 & Yes & No & No & No & No \\
\hline 3 & NASM & 43 & 1 & 22 & No & Yes & No & No & Yes \\
\hline 4 & RMFA & 29 & 1 & 3 & No & No & Yes & No & No \\
\hline 5 & Oncoplastic & 29 & 1 & 20 & No & No & No & Yes & Yes \\
\hline 6 & SSM & 37 & 1 & 17 & No & Yes & No & No & Yes \\
\hline 7 & Burn & 32 & 1 & 6 & No & No & No & No & No \\
\hline 8 & TRAM & 35 & 3 & 30 & No & No & No & Yes & Yes \\
\hline 9 & RMFA & 27 & 1 & 7 & No & No & No & No & No \\
\hline 10 & Oncoplastic & 37 & 1 & 25 & No & No & yes & Yes & Yes \\
\hline 11 & Poland S & 18 & 2 & 6 & No & No & No & No & No \\
\hline 12 & PMR LD, TE and prosthesis & 63 & 3 & 17 & Yes & No & No & Yes & Yes \\
\hline 13 & SSM & 45 & 1 & 10 & Yes & No & No & No & Yes \\
\hline 14 & TRAM & 42 & 2 & 12 & No & Yes & No & Yes & Yes \\
\hline 15 & Oncoplastic & 45 & 1 & 21 & No & No & Yes & Yes & Yes \\
\hline 16 & NAS M & 56 & 1 & 25 & No & No & Yes & No & Yes \\
\hline 17 & TRAM & 33 & 2 & 18 & No & No & No & Yes & Yes \\
\hline 18 & Poland S & 16 & 3 & 7 & No & No & No & No & No \\
\hline 19 & NAS M & 39 & 1 & 11 & No & No & No & No & Yes \\
\hline 20 & RMFA & 40 & 1 & 9 & Yes & No & Yes & No & No \\
\hline 21 & Oncoplastic & 46 & 1 & 23 & Yes & No & No & Yes & Yes \\
\hline 22 & $\mathrm{JH}$ & 14 & 2 & 6 & No & No & No & No & No \\
\hline 23 & PMR: LD,TE and prosthesis & 35 & 2 & 13 & No & No & No & Yes & Yes \\
\hline 24 & TRAM & 57 & 3 & 15 & Yes & No & No & Yes & Yes \\
\hline 25 & $\mathrm{JH}$ & 18 & 1 & 8 & No & No & No & No & No \\
\hline 26 & NASM & 47 & 1 & 16 & No & Yes & No & No & Yes \\
\hline 27 & PMR: LD, TE and prosthesis & 48 & 3 & 10 & No & No & Yes & Yes & Yes \\
\hline 28 & Burn & 37 & 2 & 5 & No & No & No & No & No \\
\hline 29 & TRAM & 53 & 2 & 8 & No & No & Yes & Yes & Yes \\
\hline 30 & Oncoplastic & 34 & 1 & 25 & No & No & No & Yes & Yes \\
\hline 31 & SSM & 46 & 1 & 18 & No & No & Yes & No & Yes \\
\hline 32 & PMR: LD, TE and prosthesis & 51 & 3 & 14 & No & No & No & Yes & Yes \\
\hline 33 & $\mathrm{JH}$ & 16 & 1 & 8 & No & No & No & No & No \\
\hline 34 & Oncoplastic & 49 & 1 & 16 & No & No & No & Yes & Yes \\
\hline 35 & Oncoplastic & 61 & 1 & 19 & Yes & No & Yes & Yes & Yes \\
\hline 36 & TRAM & 29 & 2 & 4 & No & No & No & Yes & Yes \\
\hline 37 & Burn & 29 & 1 & 7 & No & No & No & No & No \\
\hline 38 & Oncoplastic & 50 & 1 & 10 & No & No & Yes & Yes & Yes \\
\hline 39 & TRAM & 41 & 2 & 6 & No & Yes & No & Yes & Yes \\
\hline 40 & RMFA & 35 & 1 & 4 & No & No & No & No & No \\
\hline 41 & PMR: LD, TE and prosthesis & 45 & 2 & 11 & No & No & No & Yes & Yes \\
\hline DM & \multicolumn{9}{|l|}{ : Diabetes Mellitus. } \\
\hline & \multicolumn{9}{|l|}{ : Radiotherapy. } \\
\hline RMFA & \multicolumn{3}{|c|}{ A : Recurrent Multiple Fibro Adenoma. } & \multicolumn{6}{|c|}{ NASM : Nipple Areola Sparing Mastectomy. } \\
\hline $\mathrm{JH}$ & \multirow{2}{*}{\multicolumn{3}{|c|}{$\begin{array}{l}\text { : Juvenile Hypertrophy. } \\
\text { : Post Mastectomy Reconstruction. }\end{array}$}} & \multirow{2}{*}{\multicolumn{6}{|c|}{$\begin{array}{l}\text { TRAM : Transverse Rectus } \\
\text { TE : Tissue Expander. }\end{array}$}} \\
\hline PMR & & & & & & & & & \\
\hline
\end{tabular}


Table (2): Patient's categories and type of surgical intervention.

\begin{tabular}{|c|c|c|}
\hline Classification of breast asymmetry (Nahai system) & $\begin{array}{l}\text { No. of } \\
\text { patients }\end{array}$ & Treatment \\
\hline \multicolumn{3}{|l|}{ Primary breast asymmetry (congenital) $(n=3)$ : } \\
\hline \multirow[t]{2}{*}{ - Poland syndrome } & 2 & $\begin{array}{l}\text { - LD flap, tissue expander, prosthesis, fat grafting, contralateral } \\
\text { SOS technique mastopexy. }\end{array}$ \\
\hline & 1 & $\begin{array}{l}\text { - Tissue expander, prosthesis, NAC transposition, contralateral } \\
\text { SOS technique mastopexy. }\end{array}$ \\
\hline \multirow{3}{*}{$\begin{array}{l}\text { Secondary breast asymmetry (developmental) }(n=3) \text { : } \\
\text { - Juvenile breast hypertrophy }\end{array}$} & & \\
\hline & 1 & $\begin{array}{l}\text { - Reduction mammoplasty using superior pedicle and SOS } \\
\text { marking technique. }\end{array}$ \\
\hline & 2 & $\begin{array}{l}\text { - Reduction mammoplasty using inferior pedicle and SOS } \\
\text { marking technique. }\end{array}$ \\
\hline \multirow{2}{*}{$\begin{array}{l}\text { Tertiary breast asymmetries (acquired) }(n=35) \text { : } \\
\text { - Infection "following granulomatous mastitis" }\end{array}$} & 1 & \\
\hline & 3 & $\begin{array}{l}\text { - Tissue expander, prosthesis, NAC reconstruction, contralateral } \\
\text { SOS technique mastopexy. }\end{array}$ \\
\hline \multirow[t]{2}{*}{ - Burn } & 3 & - Scar revision, Z-Pasty, SOS technique mastopexy. \\
\hline & 1 & $\begin{array}{l}\text { - Tumor excision, superomedial pedicle and SOS marking } \\
\text { technique mastopexy. }\end{array}$ \\
\hline - Recurrent multiple Benign tumor excision $n=4$ & 1 & $\begin{array}{l}\text { - Tumor excision, inferior pedicle and SOS marking technique } \\
\text { mastopexy. }\end{array}$ \\
\hline - Malignant tumor excision: & 4 & - Superior pedicle, SOS marking technique in both sides. \\
\hline \multirow[t]{2}{*}{ 1- Oncoplastic procedure $(n=8)$} & 3 & $\begin{array}{l}\text { - Superior medial pedicle, SOS marking technique in both } \\
\text { sides. }\end{array}$ \\
\hline & 3 & - Inferior pedicle, SOS marking technique in both sides. \\
\hline \multirow[t]{2}{*}{ 2- Nipple areola sparing mastectomy $\mathrm{N}=4$} & 1 & - Mastectomy, LD, prosthesis, contralateral SOS mastopexy. \\
\hline & 3 & - Mastectomy, prosthesis, contralateral SOS mastopexy. \\
\hline 3- Skin sparing mastectomy $\mathrm{N}=3$ & 12 & - Mastectomy, LD, prosthesis contralateral SOS mastopexy. \\
\hline 4- Post modified radical mastectomy reconstruction: & 1 & $\begin{array}{l}\text { - TRAM flap, immediate contralateral SOS mastopexy, NAC } \\
\text { reconstruction. }\end{array}$ \\
\hline \multirow[t]{2}{*}{ - TRAM N=7 } & 6 & • TRAM flap, immediate contralateral SOS mastopexy. \\
\hline & 4 & $\begin{array}{l}\text { - LD flap, tissue expander, prosthesis, immediate contralateral } \\
\text { SOS mastopexy. }\end{array}$ \\
\hline - $\mathrm{LD}$, tissue expander and prosthesis $\mathrm{N}=5$ & 1 & $\begin{array}{l}\text { - LD flap, tissue expander, prosthesis, immediate contralateral } \\
\text { SOS mastopexy, NAC reconstruction. }\end{array}$ \\
\hline
\end{tabular}

Table (3): Patient satisfaction score "Harvard scale".

\begin{tabular}{|c|c|}
\hline $\begin{array}{l}\text { Patient } \\
\text { satisfaction }\end{array}$ & Description \\
\hline Excellent & $\begin{array}{l}\text { - Treated breast nearly identical to untreated } \\
\text { breast. }\end{array}$ \\
\hline Good & - Treated breast slightly different than untreated. \\
\hline Fair & $\begin{array}{l}\text { - Treated breast clearly different from untreated } \\
\text { but not seriously distorted. }\end{array}$ \\
\hline Poor & - Treated breast seriously distorted. \\
\hline
\end{tabular}

Table (4): Percentage of complications in the three groups of patients.

\begin{tabular}{llll}
\hline & Group & Group & Group \\
& \multicolumn{1}{c}{1} & \multicolumn{1}{c}{2} & \multicolumn{1}{c}{3} \\
\hline Hematoma & $0 \%$ & $0 \%$ & $5.3 \%$ \\
Seroma & $66.7 \%$ & $0 \%$ & $21 \%$ \\
Prolonged pain & $0 \%$ & $21 \%$ & $5.3 \%$ \\
Infection & $0 \%$ & 0 & $5.3 \%$ \\
Delayed healing and flap necrosis & $0 \%$ & $10.5 \%$ & $5.3 \%$ \\
Compromised NAC vascularity & $0 \%$ & $5.3 \%$ & $5.3 \%$ \\
Altered NA sensation & $0 \%$ & $21 \%$ & $21 \%$ \\
Hypertrophic scarring & $33.3 \%$ & $0 \%$ & $0 \%$ \\
Secondary procedure & $33.3 \%$ & $5.3 \%$ & $5.3 \%$ \\
\hline
\end{tabular}

\section{RESULTS}

This cohort retrospective study included 41 patients suffering from breast asymmetry and underwent breast reconstruction surgeries and immediate symmetry procedure in the contralateral breast, with age range (14-63 years) and mean age (38.3 \pm 12.5 years). Among these 41 patients; 3 patients $(7.4 \%)$ were due to congenital cause (Poland syndrome) with mean age (18 \pm 2 years), 19 patients $(46.3 \%)$ were due to developmental causes with mean age ( $35.3 \pm 12.2$ years), while 19 patients $(46.3 \%)$ were due to iatrogenic causes with mean age (44.5 \pm 8.9 years).

Operative time varied among each group; $(3 \pm 0.6)$ in congenital group (group 1), $(3.3 \pm 0.5)$ in developmental group (group 2$)$ and $(4 \pm 0.8)$ in iatrogenic group, see Diagram (1).

Follow-up time varied among groups; (10.6 \pm 7.2 months) in group $1,(12.3 \pm 7.6$ months) in group 2 , and (14.6 \pm 6.4 months) in group 3 . 
Post-operative patient's assessment was done objectively by using the 5 point subscale. Data analysis showed highest score in group $1(8 \pm 0.9)$, then group $2(7.6 \pm 1)$, while the lowest one was in group (7.1 \pm 1$)$. See Diagram (2).

Patient satisfaction score "Harvard scale" was used for subjective evaluation. Data conducted from this scale showed the same sequence as 5 point subscale; highest Score was in group $1(7 \pm 1)$, followed by group $2(6.8 \pm 1)$ and the lowest score was in group $3(6.7 \pm 0.9)$, see Diagram (3).

In this current study, the mean of overall 5 point scale assessment for all 41 patients (objective method) was (7.4 \pm 1$)$ while the mean of overall Harvard satisfaction scale for all patients (subjective method) was $(6.6 \pm 0.9)$. The overall correlation between the objective assessment " 5 point subscale" and the subjective assessment "Harvard scale" was done showing significant correlation with a $p$-value $<0.01$, see Diagram (4).

Post-operative complication rate for all groups of patients were recorded and analyzed. All recorded complications were analyzed and tabulated including hematoma, seroma, prolonged pain, infection, delayed healing and flap necrosis, compromised NAC vascularity, altered NA sensation, hypertrophic scarring, and the need for secondary procedure, see (Table 4) and Diagram (5). Some of our patient's pre and post-operative photos are shown in Figs. (2-11).

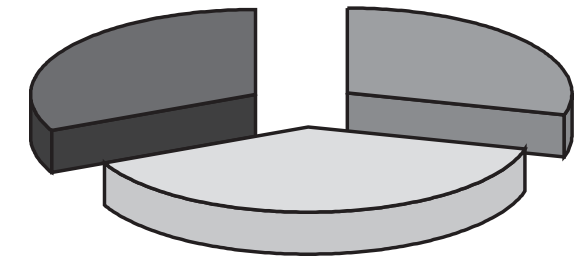

Group $1 \square$ Group $2 \square$ Group 3

Diagram (1): Operative time spent in each group of patients.

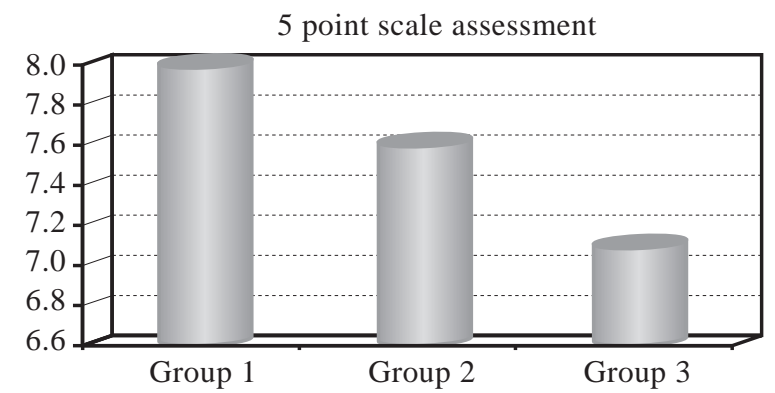

Diagram (2): Relation between the three groups using the 5 point objective analysis.

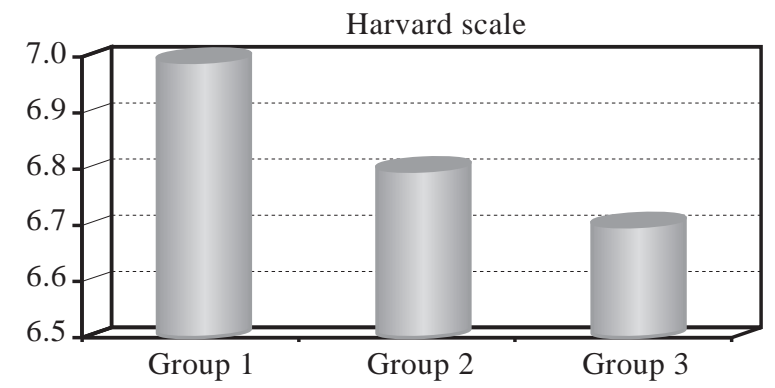

Diagram (3): Relation between the three groups using the Harvard scale.
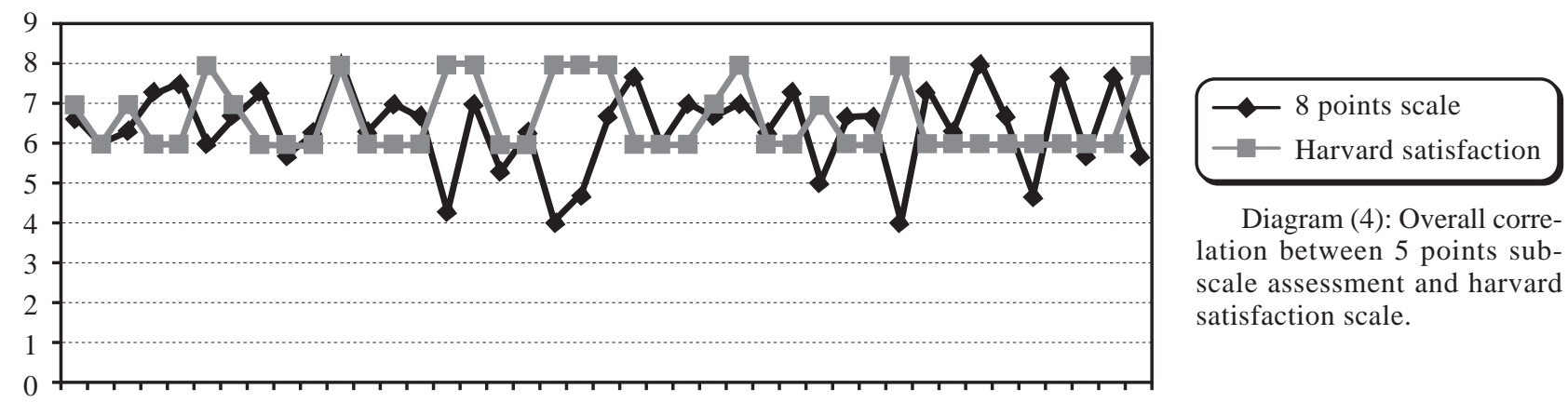

Diagram (4): Overall correlation between 5 points subscale assessment and harvard satisfaction scale.

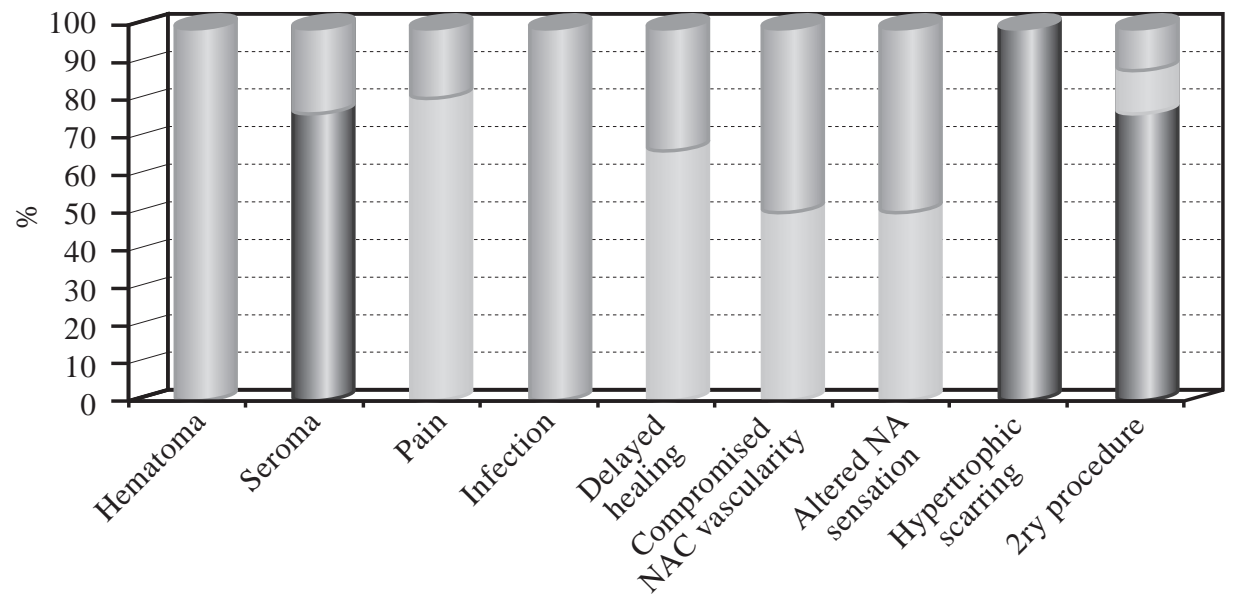

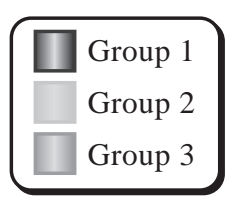

Diagram (5): Complication rate and correlation among the three groups of patients. 

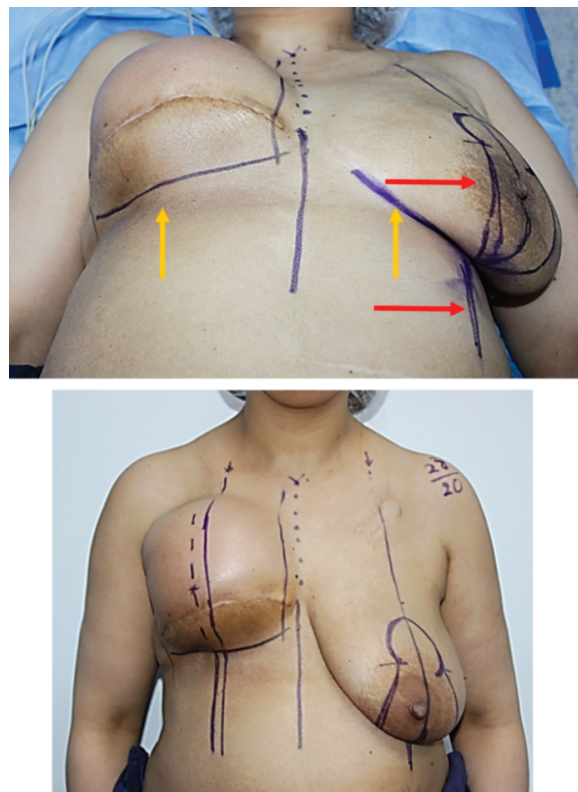
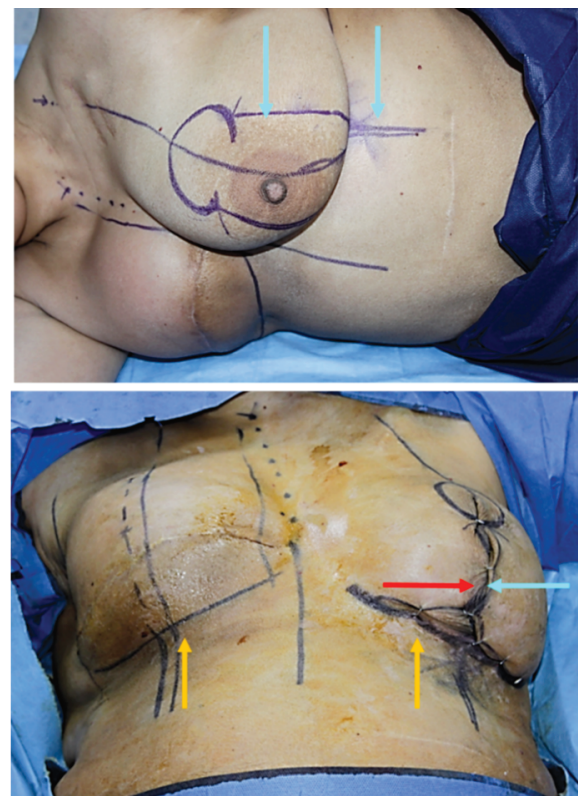

Fig. (1): Pictures showing the SOS marking technique, the (upper left) patient lying in supine position under general anesthesia and the yellow arrows point on the infra mammary fold while the red ones point on the medial limb which continues with the breast median. (The upper right) patient lying in oblique position Unger general anesthesia and the blue arrows point on the lateral limb which continues with the breast meridian. (Lower left) showing the pre-operative marking, (lower right) showing the meeting of both meridians while using a stapler to imagine an tailor the amount of skin and tissue to be excised.
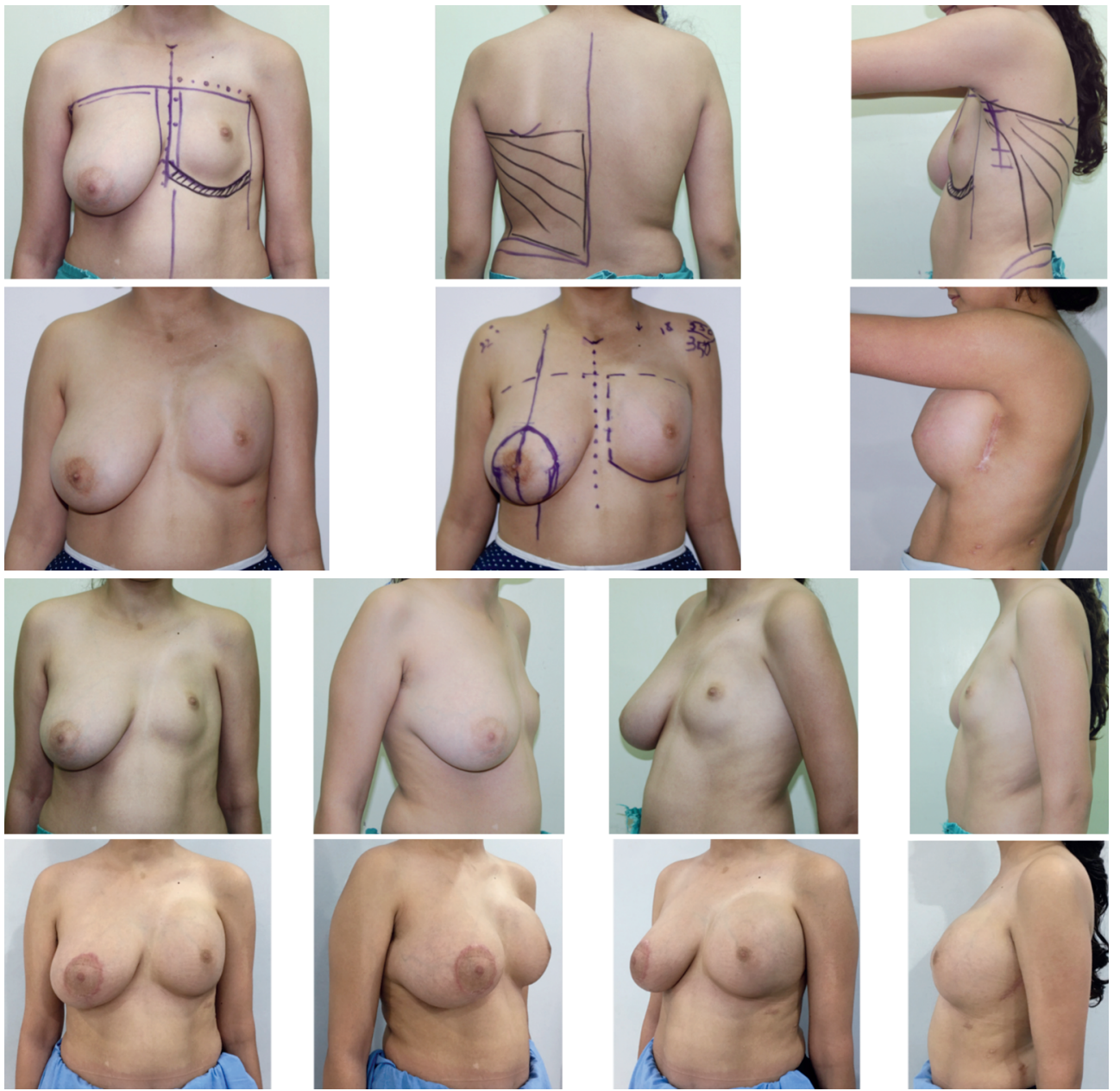

Fig. (2): Patient with Poland syndrome. The $1^{\text {st }}$ raw of photos showing the deformity, marking the anterior chest wall and the trans axillary approach for harvesting the LD flap and application of tissue expander. The $2^{\text {nd }}$ raw shows the post-operative result after inflation of the tissue expander. The $3^{\text {rd }}$ and $4^{\text {th }}$ rows shows the pre and post-operative clinical picture after definitive reconstruction with silicone implant and contralateral reduction mastopexy. 

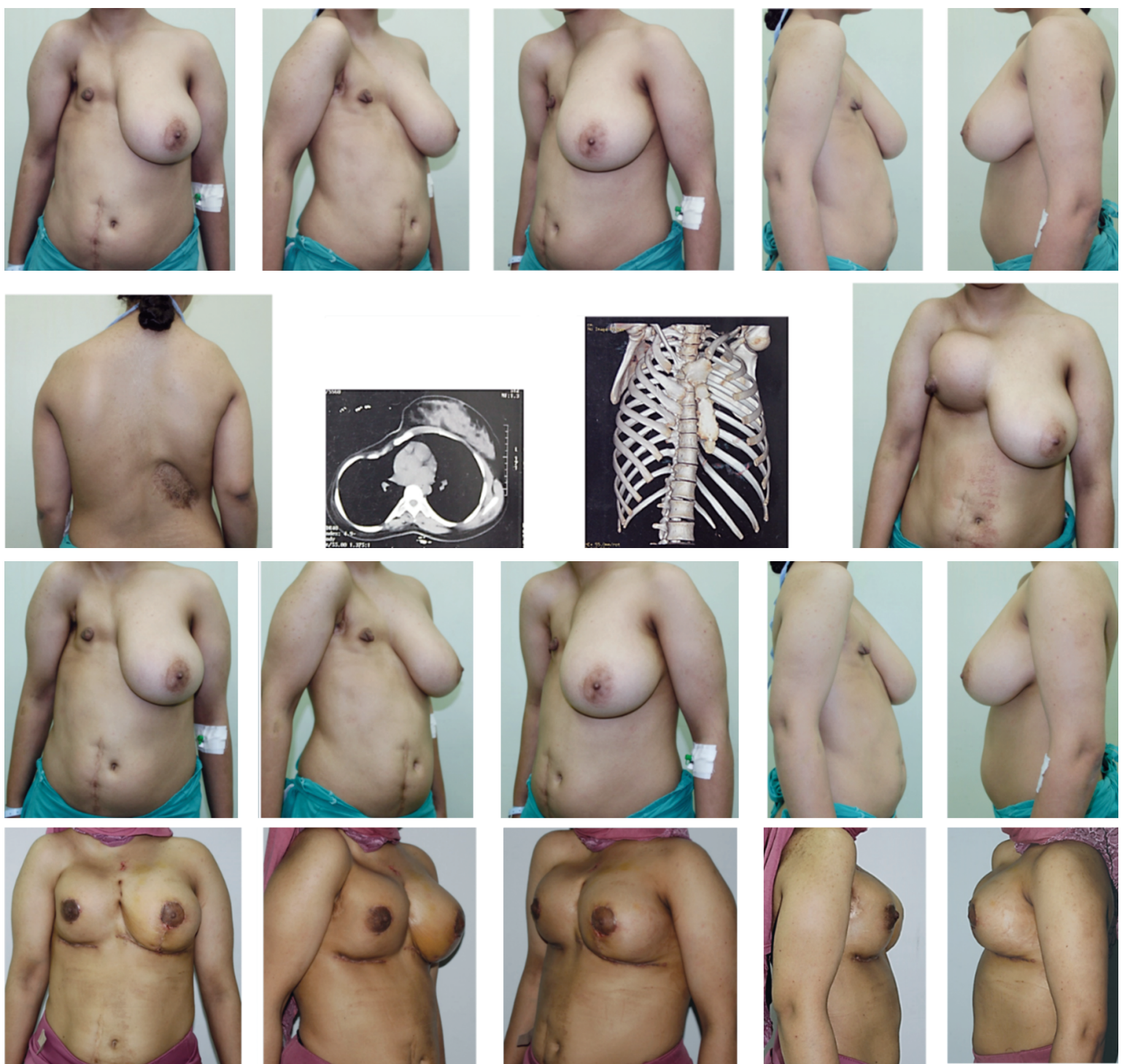

Fig. (3): Patient with Poland syndrome, sever deformity of the chest wall and spine, frozen shoulder, sand history of trauma over the back treated with split thickness skin graft and mid line lower abdominal incision. ( $1^{\mathrm{st}}$ raw) showing the pre-operative clinical picture. (2 ${ }^{\text {nd }}$ raw) after application of tissue expander, and the CT scan showing the deformity of the chest wall and spine. (3rd and $4^{\text {th }}$ rows) showing the pre and post-operative result after definitive reconstruction with silicone implant and reduction mastopexy off the contra lateral side.
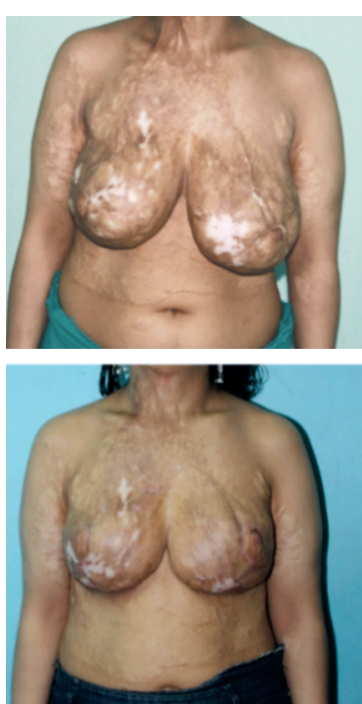
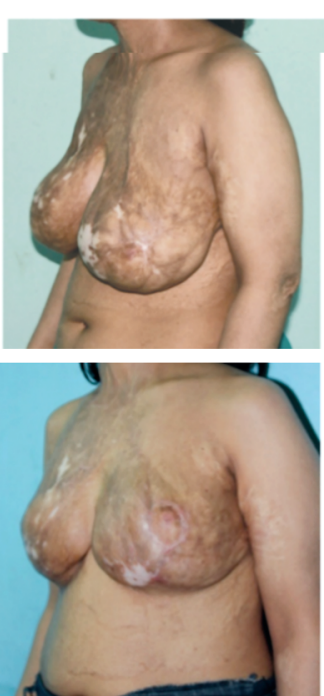
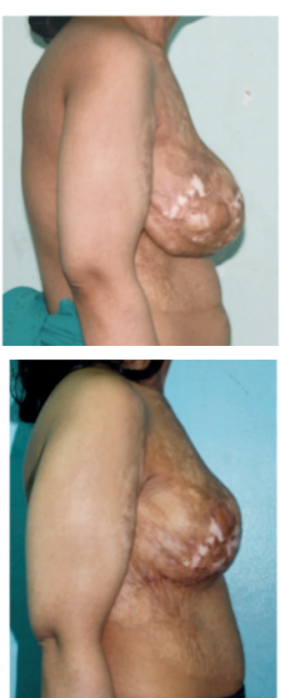
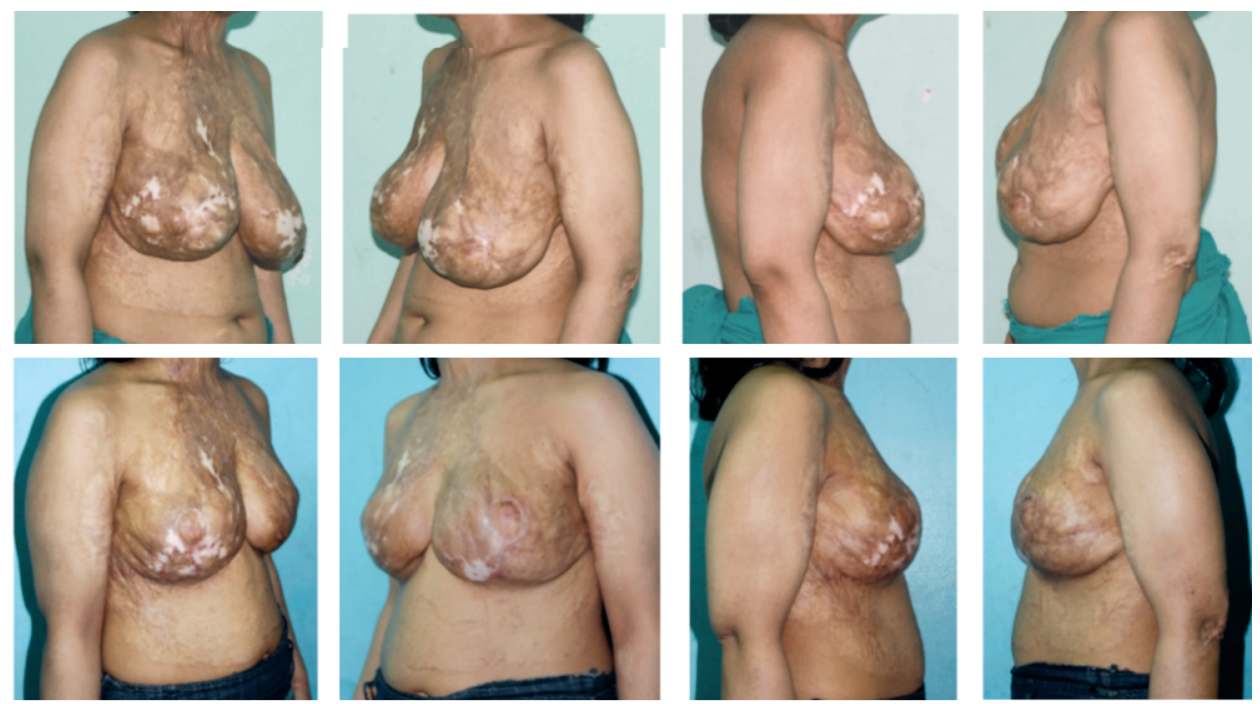

Fig. (4): Patient with bilateral post burn contractures and scaring. (Upper raw) showing the pre-operative clinical picture. (Lower raw) after release of the contractures by multiple z pasties and reduction mastopexy off both breast using the modified SOS marking technique. 

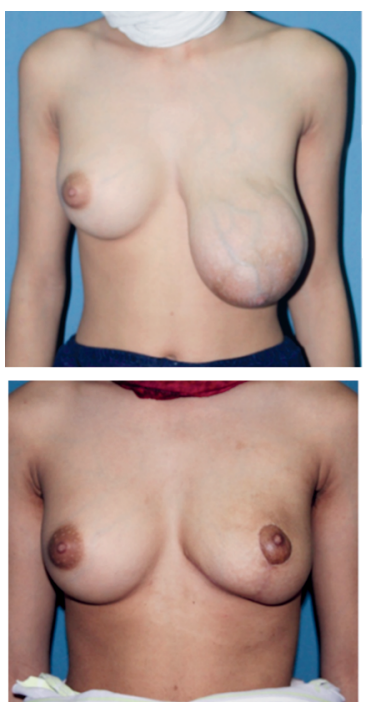
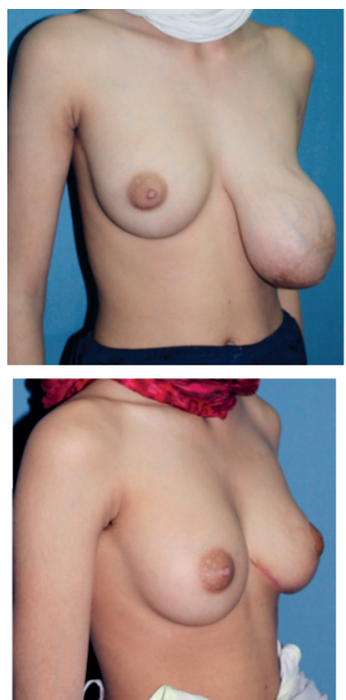
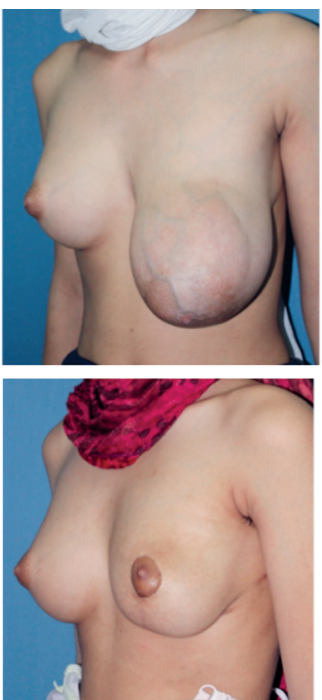
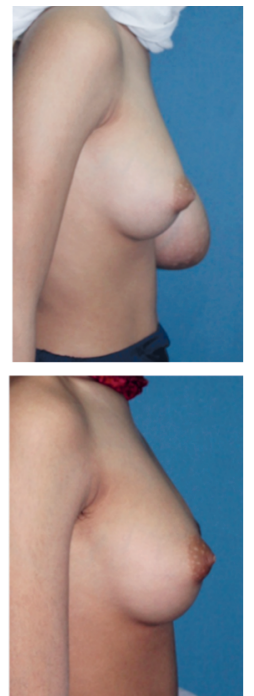

Fig. (5): Patient with unilateral juvenile hypertrophy of the breast. (Upper raw) showing the pre-operative clinical picture. (Lower raw) post-operative result after definitive reconstruction with the inferior pedicle and wise pattern skin closure by using modified SOS marking technique.
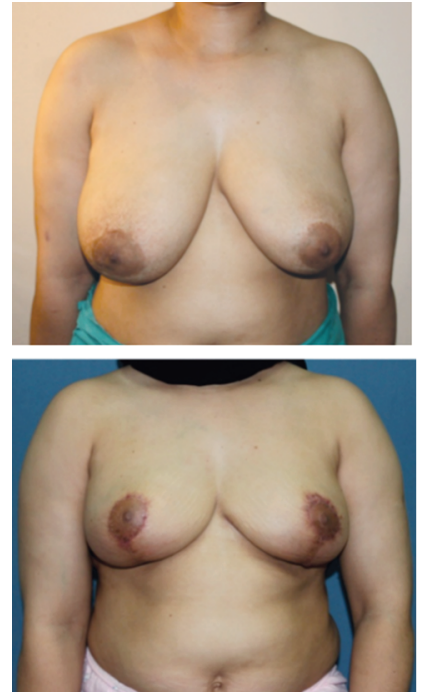
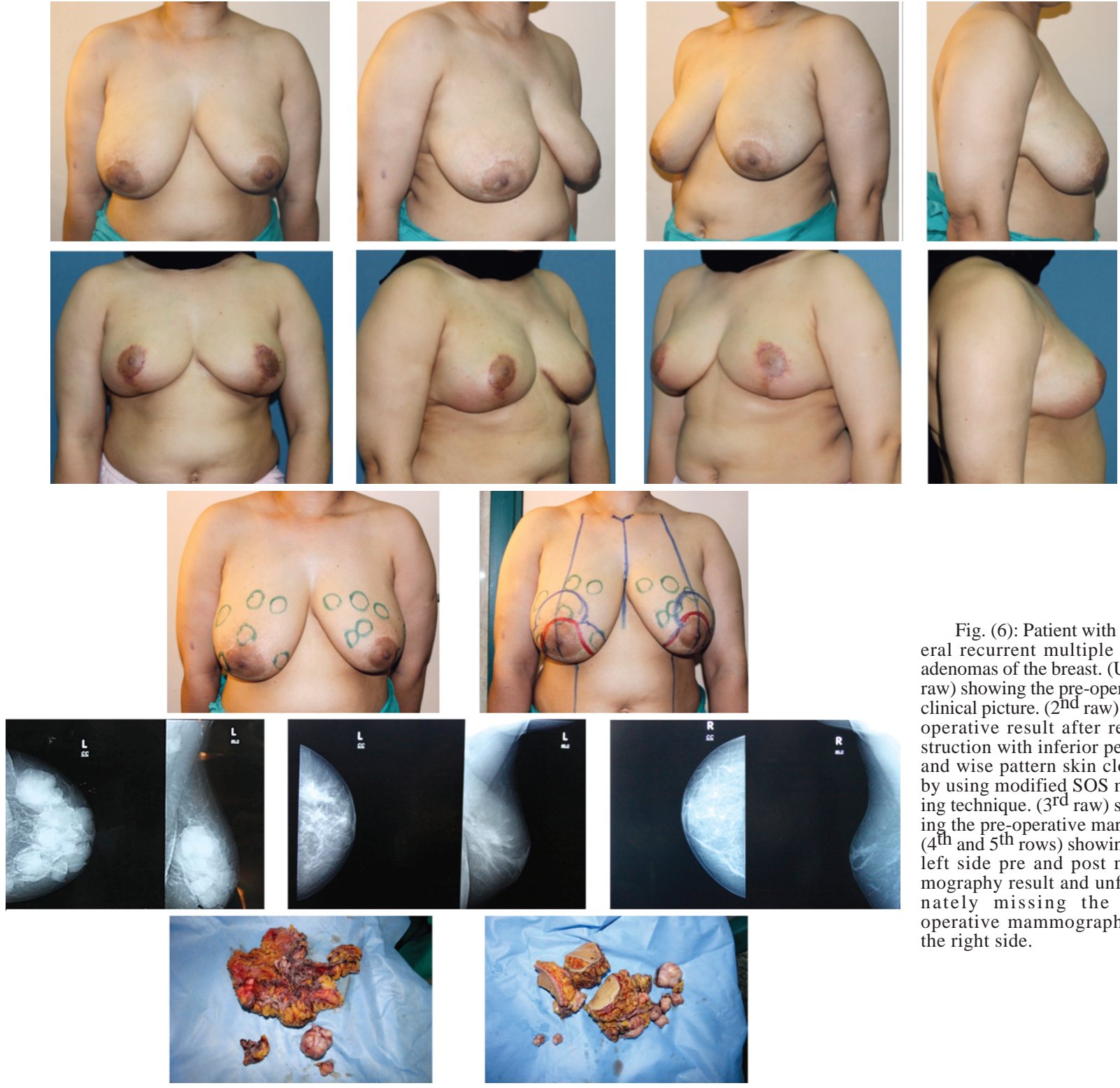

Fig. (6): Patient with bilateral recurrent multiple fibro adenomas of the breast. (Upper raw) showing the pre-operative clinical picture. ( $2^{\text {nd }}$ raw) postoperative result after reconstruction with inferior pedicle and wise pattern skin closure by using modified SOS marking technique. ( $3^{\text {rd }}$ raw) showing the pre-operative marking. ing the pre-operative marking.
(4th and $5^{\text {th }}$ rows) showing the left side pre and post mammography result and unfortunately missing the preoperative mammography on the right side. 

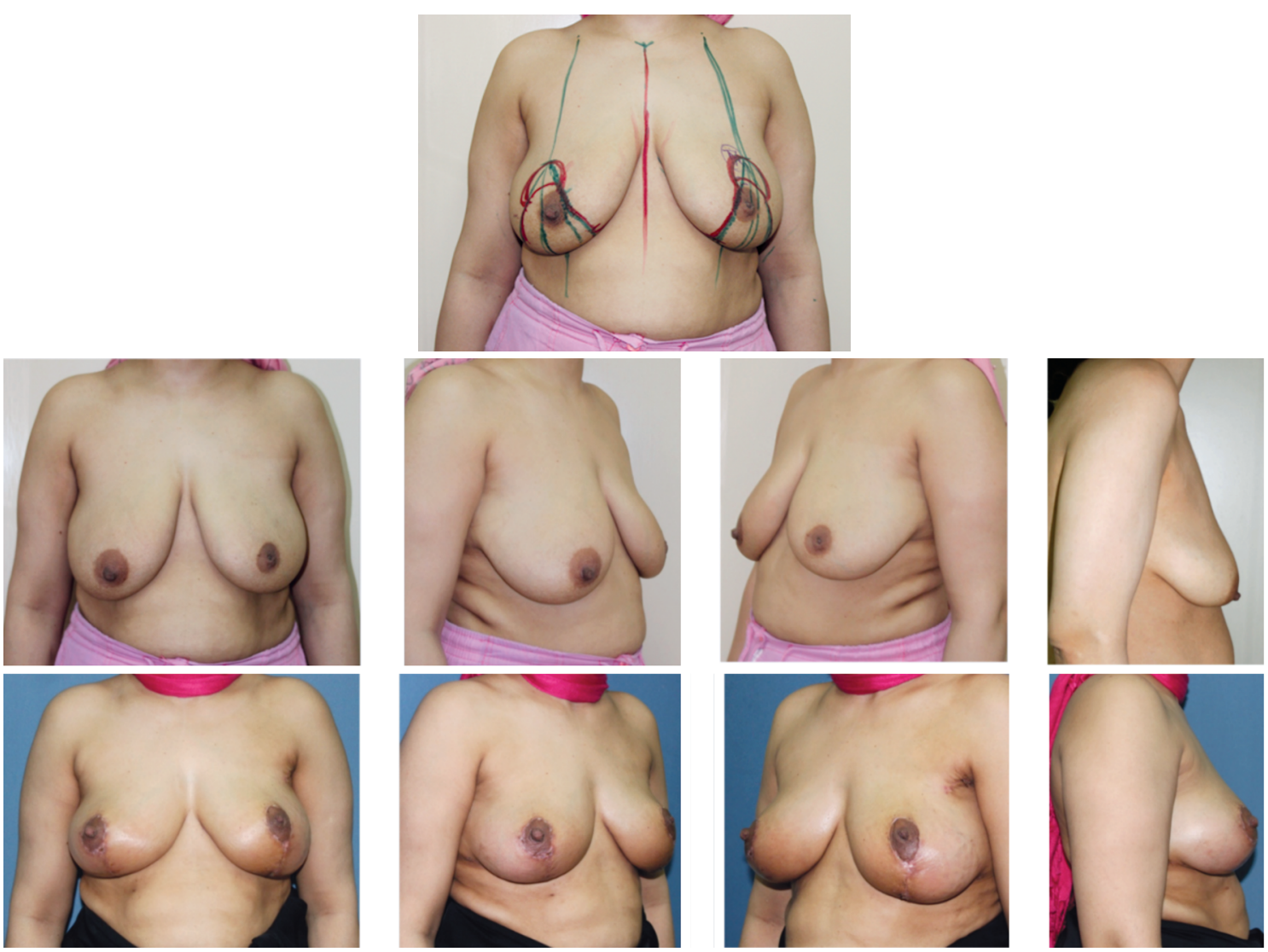

Fig. (7): Patient with malignant breast cancer (duct carcinoma in situ) underwent oncoplastic breast conservation. (Upper photo) showing the pre-operative marking and the lesion is at 12 o'clock on the left breast ( $2^{\text {nd }}$ and $3^{\text {rd }}$ rows) post-operative result after reconstruction with inferior pedicle and wise pattern skin closure by using modified SOS marking technique.

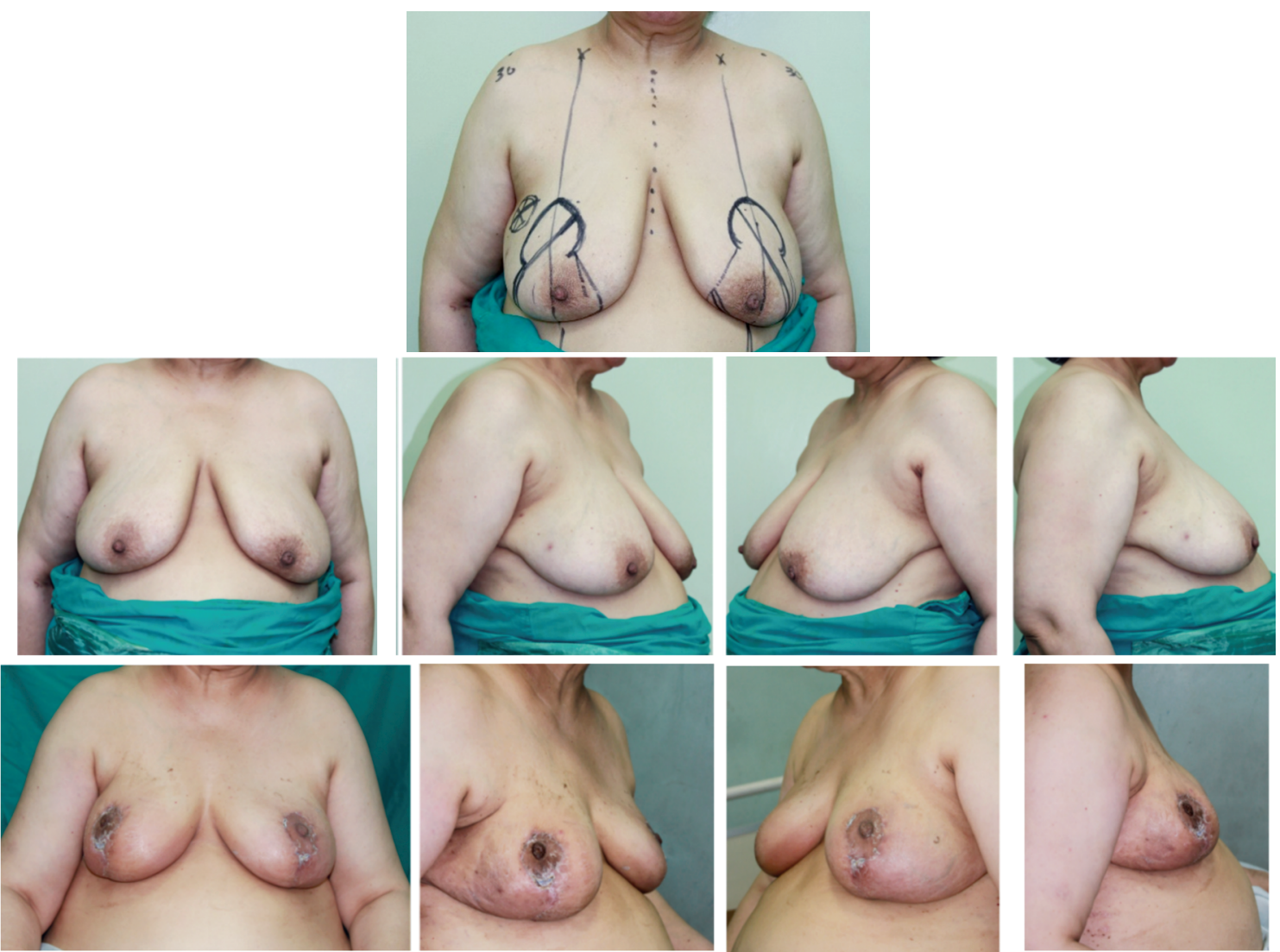

Fig. (8): Patient with malignant breast cancer (duct carcinoma) underwent oncoplastic breast conservation. (Upper photo) showing the preoperative marking and the lesion is at 11 o'clock on the right breast ( $2^{\text {nd }}$ and $3^{\text {rd }}$ rows) post-operative result after reconstruction with superior medial pedicle and wise pattern skin closure by using modified SOS marking technique. 

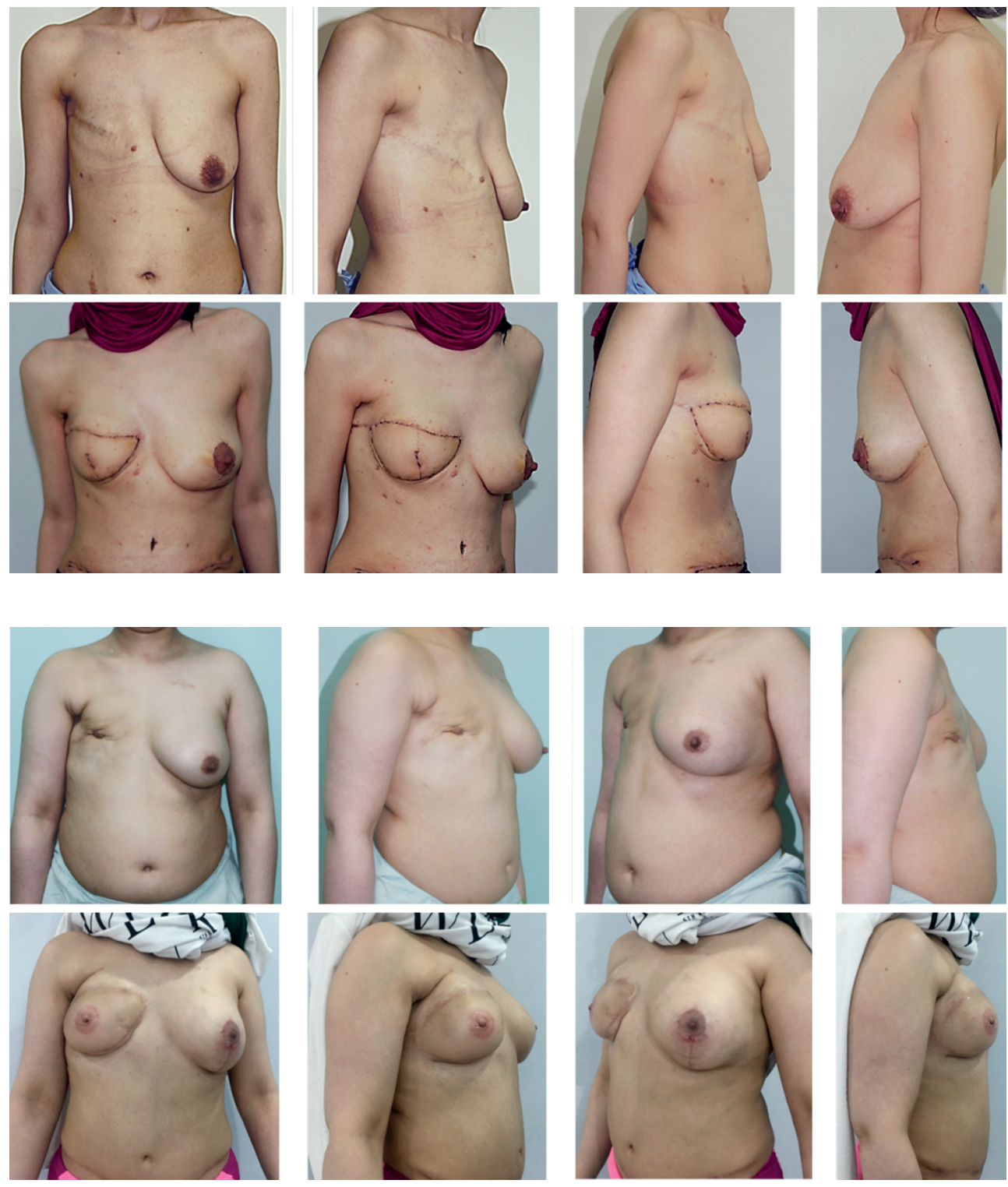

Fig. (9): Patient with post mastectomy breast deformity. (Upper row) showing the preoperative clinical picture (lower row) post-operative result after reconstruction with TRAM flap and mastopexy of the contralateral side using modified SOS marking technique.

Fig. (10): Patient with post mastectomy breast deformity. (Upper row) showing the preoperative clinical picture. (Lower row) post-operative result after reconstruction with TRAM flap, Lipofilling the upper pole of the right breast, nipple and areola reconstruction with skate flap, full thickness skin graft from the contralaral breast and mastopexy of the contralateral side using modified SOS marking technique.
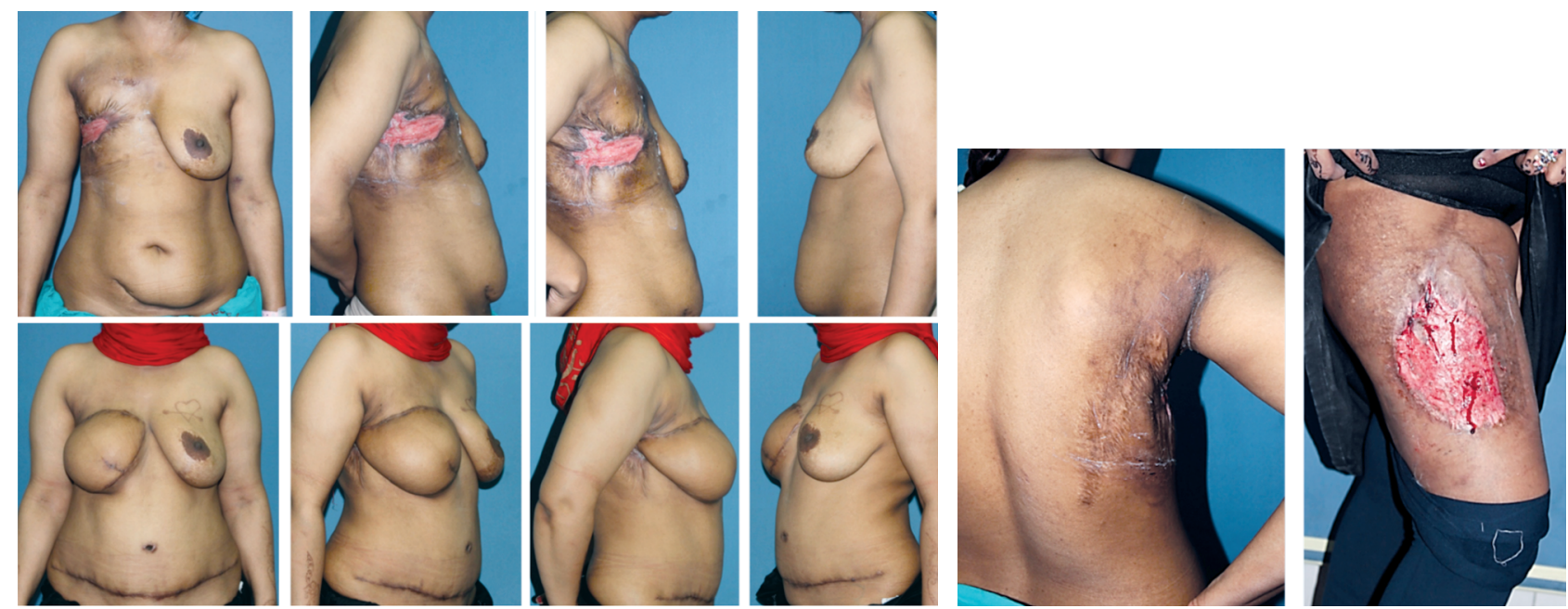

Fig. (11): Patient with post mastectomy breast deformity. ( $1^{\text {st }}$ row) showing the pre-operative clinical picture and scaring of the right side of the lower abdomen "previous appendectomy". ( $2^{\text {nd }}$ row) post-operative result after reconstruction with TRAM flap, the contralaral breast was operated previously operated upon in another hospital. (3rd row) showing failed previous two attempts to reconstruct the breast using the LD flap and anterolateral thigh flap in another hospital. 


\section{DISCUSSION}

Aesthetic parameters of the breast affect greatly the entire female beauty; therefore, congenital, developmental and iatrogenic breast asymmetry affect significantly patient's self-esteem [31,32]. Physiological breast asymmetry is a common and achieving symmetrical breasts require different strategies [33,34].

Reliable assessment for the aesthetic outcomes are scarce. It could be done through questioners answered by the patient, photograph to be assessed by other plastic surgeons, or by other professional e.g. nursing staff $[35,46]$. However, methods varies widely between studies and often they are ill defined. It is important to have standardized scoring system, to objectify the subjective aesthetic outcome.

The subjective assessment is the most commonly used method for breast aesthetic evaluation undertaken by one [47-58] or several observers [5973]. The most commonly, simple and cost effective is evaluating the static photograph and using the digital video has been proposed [74]. Potter 2011 stated the introduction of the 3-dimensional and 4-dimensional breast scanning. In our study we used both the subjective method in the form of questioner and the objective method as a standardized scoring system [75]. Patients were asked to complete a satisfaction questionnaire based on the Harvard scale, introduced by Jay Harris in 1979 and we used the scoring method described by Visser et al., [26]. To assess the breast volume, shape, symmetry, scars, and nipple areola complex. For each of these items a 5-point Likert scale is used for scoring.

Patients were classified in our study into three groups: Congenital breast deformities comprised the first group. Sir Alfred Poland in 1841 enumerated the anomalies and Patrick Wensley Clarkson in 1962 who named the associated anomalies as Poland Syndrome. The incidence is 1:20,000$1: 32,000$, three time more common in males than females and it is more commonly affecting the left than the right side. Intrauterine fetal insult occurs between the fifth and eighth weeks of gestation, and genetic predisposition is not proven yet $[\mathbf{7 6 , 7 7 ]}$. The clinical picture mandate the absence of the pectoralis major muscle "sternal head ", but a wide variety is mentioned in the literature [79].

We included three patients in our study. Two patients treated with trans axillary harvesting the latismus dorsi muscle flap and application of rounded tissue expander with an internal valve (450,
$500 \mathrm{cc}$ ) as a first stage, inflation was done exceeding the volume of the expanders and waiting for three months. The second stage was delivery of the expanders and application of breast implants and simultaneous mastopexy and or mastopexy was done in the contralateral side. A third stage was in the form of Lipofilling in the takeoff area of the breast. The third patient was treated in the same sequence without doing a latismus dorsi muscle transfer because of its atrophy, nor Lipofilling, however nipple and areola transposition was carried.

Data analysis showed the highest 5 point subscale in this group of patients $(8 \pm 0.9)$, and highest patient satisfaction score "Harvard scale" $(7 \pm 1)$. The operative time was the high in this group due to changing from lateral to supine the position during surgery and matching the best breast volume when choosing the breast implant. Seroma rate was high on the donor site, managed by adhesive compression taping and multiple cessions of drainage by syringe. One patient had trans axillary hypertrophic scar in the trans axillary approach which entailed scar revision under local anesthesia.

The second group of patients included three patients with juvenile hypertrophy of the breast. It is a benign condition where rapid, and continued breast hypertrophy occurs [80]. It is also described as virginal hypertrophy, juvenile gigantomastia, and juvenile macromastia [81,82]. Neinstein 1999 stated its rarity ( $2 \%$ of all breast lesions) after reviewing 15 publications over 40 years period [83]. Hoppe et al., 2011 reported 65 cases between 1910 and 2009 [82]. Additional nine cases from 2010 till 2017 [86-90]. The most challenging aspect in the management of JHB is the difficulty in effecting a definitive treatment. Using reduction mammoplasty techniques is ideal, reported recurrence rate is high which might necessitate secondary intervention [80-82].

Three patients with unilateral juvenile hypertrophy of the breast were included in our study. Wise pattern reduction mammoplasty utilizing the superior pedicle in one patient and inferior pedicle in two patients and SOS marking technique in the contra lateral side. No recurrence were reported with an average follow-up time (12.3 \pm 7.6 months). The operative time was high due to the time needed for excision of the huge size breast, adequate hemostasis and symmetry reduction and mastopexy on the contralateral side. Patient's satisfaction and the objective 5 point subscale analysis was $(6.8 \pm 1)$, (7.6 \pm 1$)$ respectively denoting above average aesthetic outcome. Post-operative complication rate 
was high as regard prolonged breast pain due to the skeletal neck and shoulder pain which takes few months to recover. Altered nipple and areola sensation and vascularity due to the extensive dissection and excision of the pathological breast tissue. Secondary sutures was done in one patient had delayed wound healing over the meeting point between the horizontal and vertical incision.

In our study the third group of patients included: Infection, post burn scarring, benign and malignant tumor excision and post mastectomy asymmetry. Granulomatous mastitis and post burn scaring significantly affects both the size and contour of the breast with variable degrees of nipple areola complex affection. If the insult occurs before puberty breast development will be affected. If it is after puberty breast shape will be altered due to the presence of scar contractures which alter the parenchyma of the breast [91-94]. One patient with post granulomatous mastitis asymmetry included in the study managed by: Tissue expansion (rounded expander $450 \mathrm{cc}$, over inflated $600 \mathrm{cc}$ and left for three months) followed by prosthesis reconstruction and symmetry SOS mastopexy on the contralateral side. Three months later skate flap and full thickness skin graft were used to reconstruct the nipple areola complex. Post burn scaring of the breast included three patients managed by scar revision, Z-Pasty and bilateral SOS mastopexy.

Breast-Conserving Therapy (BCT) is one of the most effective and commonly used surgical oncological therapy for breast cancer, however it but it significantly affect breast symmetry. This depend on the balance between the volume of tissue to be excised "lumpectomy" and the total breast volume [95-103]. Patients with ptotic and hypertrophic breasts with a relatively large lumpectomy volume, immediate oncoplastic reconstruction could be done by means of reduction or mastopexy pattern techniques, at the time of the lumpectomy. The aim is to obliterate the lumpectomy dead space and reduce the potential breast asymmetry and distortion that will follow after radiation therapy [104].

Oncoplastic reduction mastopexy procedures are safe, showing high patient satisfaction and favorable aesthetic outcome. This procedure can be done immediately, at the time of the lumpectomy or delayed, after the radiation therapy [104-119]. Each protocol has its advantage and disadvantage regard the tumor margins, complications (radiated tissue), secondary intervention, and aesthetic results [119].
Weichman et al., retrospectively studied patients undergone BCT without immediate oncoplastic reconstruction looking for improving the aesthetic outcome after completion of the oncologic therapy. He concluded that irradiation and previous surgical intervention is a surgical challenge to correct the breast deformity asymmetry with four to ten time's higher risk of delayed wound healing, infection, and scarring in breast reduction after BCT [114].

Others demonstrated lower complication rates in post irradiated breast asymmetry management when surgical patient education and surgical refinement in the form of: Avoiding excessive skin undermining [114-120], wide nipple areola complex pedicle [115-117], and thick skin flaps dissection [115-117,120]. A major drawback is the limited number of patients included in these studies [114120]. Barnea 2019 studied 25 patients with post irradiated breast deformity looking for breast symmetry procedure. The main outcome of the study was the complication rate and reoperations but no aesthetic evaluation were provided [121].

In our study the third group of patients included patients with recurrent multiple benign tumor, oncoplastic procedures, nipple areola sparing mastectomy, skin sparing mastectomy and post modified radical mastectomy reconstruction, see (Table 2). The operative time was maximum in this group of patients $(4 \pm 0.8)$ which explains the complexity and the surgical challenge in such patients. Oncoplastic procedures entails intraoperative frozen section biopsy, changing the operative position when latismus dorsi is used for post mastectomy reconstruction, and matching symmetry in patients with TRAM flap reconstruction. The longest period of follow-up was noted (14.6 \pm 6.4 months) with no recurrence of malignancy. Objectively by using the 5 point subscale was the lowest as compared

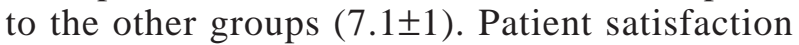
score "Harvard scale" was lowest score as well (6.7 \pm 0.9$)$.

Out of 35 patients in the third group of patients, one patient with post mastectomy deformity and history of radiotherapy, reconstructed with LD flap and application of tissue expander developed postoperative hematoma (after 24 hours), at the anterior chest wall (recipient site) required evacuation and hemostasis under general anesthesia. One patient with history of smoking treated with nipple areola sparing mastectomy, application of breast implant and contralateral SOS mastopexy, developed subcutaneous seroma over the anterior chest wall and ultrasound guided aspiration was used for drainage. Compromised NAC vascularity which managed 
with dailey dressing. Patient complaint of altered nipple and areola sensation which is a normal squeal in this type of mastectomies. And lastly 53 years old patient with history of radiotherapy and hypertension having post modified radical mastectomy deformity, reconstructed with TRAM flap and immediate contralateral SOS mastopexy, and developed fat necrosis followed by wound infection and disruption of the recipient site, which required debridement of the necrotic fat and 2ry sutures under general anesthesia.

The study has a number of week points. It is a cohort retrospective study with potential bias in patient selection and outcome, objective analysis using soft wear programs for accurate breast measurements could be used in further studies.

\section{Conclusion:}

It is a novel marking technique solved the dilemma of changing the pre-operative plane according to the intraoperative judgment and altering the amount of tissue to be excised or reconstructed in patients suffering from congenital and pathological breast asymmetry. It is technical easy to learn, reliable with satisfactory aesthetic outcome especial in congenital asymmetries, with acceptable complication rate.

\section{Acknowledgments:}

We would like to thank the breast multidisciplinary team and nursing staff for their preoperative, operative assistance and post-operative care of the patients included in the study.

\section{REFERENCES}

1- Nahai F.: The art of aesthetic surgery: Principles and techniques. Quality Medical Publishing, St. Louis, MO, 2005.

2- Sabino N.M., Da Silva A.L., Garcia E.B., Freire M. AND Ferreira L.: Quality of life and self-esteem after breast asymmetry surgery. Aesthet. Surg. J., Nov.-Dec., 27 (6): 616-21, 2007.

3- Waljee J.F., Hu E.S., Ubel P.A., Smith D.M., Newman L.A. and Alderman A.K.: Effect of esthetic outcome after breast-conserving surgery on psychosocial functioning and quality of life. J. Clin. Oncol., 26 (20): 3331-7, 2008.

4- Pusic A.L., Chen C.M., Cano S., et al.: Measuring quality of life in cosmetic and reconstructive breast surgery: A systematic review of patient-reported outcomes instruments. Plast. Reconstr. Surg., 120: 823-37, 2007.

5- Bezuhly M., Bucholtz J. and Sigurdson L.: Less scarring or more symmetry? Reconstruction following metachronous bilateral breast cancer. J. Plast. Reconstr. Aesthet. Surg., 65: 1595-7, 2012.

6- Craft R.O., Colakoglu S., Curtis M.S., et al.: Patient satisfaction in unilateral and bilateral breast reconstruction [outcomes article]. Plast. Reconstr. Surg., 127: 1417-24, 2011.
7- Adimulam G., Challa V.R., Dhar A., Chumber S., Seenu V. and Srivastava A.: Assessment of cosmetic outcome of oncoplastic breast conservation surgery in women with early breast cancer: A prospective cohort study. Indian J. Cancer, 51 (1): 58e62. https://doi.org/10.4103/0019509X.134629, 2014

8- Clough K.B., Lewis J.S., Couturaud B., Fitoussi A., Nos C. and Falcou M.C.: Oncoplastic techniques allow extensive resections for breast-conserving therapy of breast carcinomas. Ann. Surg., 237 (1): 26-34, 2003.

9- Clough K.B., Oden S., Ihrai T., Massey E., Nos C. and Sarfati I.: Level 2 oncoplastic surgery for lower inner quadrant breast cancers: The LIQ-V mammoplasty. Ann. Surg. Oncol., 20: 3847e54. https://doi.org/10.1245/s10434013-3085-4, 2013.

10- Hernanz F., Gonz_alez-Noriega M., P_erez R.V., G_omezFleitas M.: Versatility of therapeutic reduction mammoplasty in oncoplastic breast conserving surgery. World J. Surg. Proced., 5 (3): 217e22. https://doi.org/10.5412/ wjsp.v5.i3.217, 2015.

11- Acea Nebril B.: Patient information in oncoplastic surgery for breast cancer. Cir. Esp., 82 (4): 204-8, 2007.

12- Semprini G., Cattin F., Vaienti L., Brizzolari M., Cedolini C. and Parodi P.C.: Oncoplastic surgery and cancer relapses: cosmetic and oncological results in 489 patients. Breast, 22 (5): 946e51. https://doi.org/10.1016/j.breast. 2013.05.008.7-12, 2013.

13- Hansje P. Smeele a, Eline M.L. Van Der Does De Willebois a, Yassir Eltahir b, Geertruida H. De Bock c, Vera C. Van Aalst $b$ and Liesbeth Jansen a: Acceptance of contralateral reduction mammoplasty after oncoplastic breast conserving surgery: A semi-structured qualitative interview study H.P. Smeele et al., The Breast, 45: 97-103, 2019.

14- Wise R.J.A.: Preliminary report on a method of planning the mammaplasty. Plast. Reconstr. Surg., 17: 367, 1956.

15. Palumbo S.K., Shifren J. and Rhee C.: Modifications of the Lejour vertical mammaplasty: Analysis of results in 100 consecutive patients. Ann. Plast. Surg., 40: 354, 1998.

16- Courtiss E.H. and Goldwyn R.M.: Reduction mammoplasty by the inferior pedicle technique. Plast. Reconstr. Surg., 59: 500, 1977.

17- Kavka S.: A simple device for marking the areola in vertical mammaplasty. Plast. Reconstr. Surg., 103: 2087, 1999.

18- Mendez-Fernandez M.A.: An easy-to-make, easy-to-use device For pre-operative marking for reduction mammoplasty and mastopexy. Ann. Plast. Surg., 26: 602, 1991.

19- Lazarus D.: A new template-goniometer for marking the wise keyhole pattern of reduction mammaplasty. Plast. Reconstr. Surg., 101: 171, 1998.

20- Beer G.M., Morgenthaler W., Spicher I. and Meyer V.E.: Modifications in vertical scar reduction. Br. J. Plast. Surg., 54: 341, 2001.

21- Paloma V., Samper A. and Sanz J.A.: Simple device for marking the areola in Lejour's mammaplasty. Plast. Reconstr. Surg., 103: 2134, 1998.

22- McKissock P.K.: Reduction mammaplasty by the vertical bipedicle flap technique. Clin. Plast. Surg., 3: 309, 1976. 
23- Gasperoni C. and Salgarello M.: Pre-operative breast marking in reduction mammaplasty. Ann. Plast. Surg., 19: 306, 1987.

24- Nahai F.: The art of aesthetic surgery: Principles and Techniques. Quality Medical Publishing, St. Louis, MO, 2005.

25- Al-Ghazal S.K. and Blamey R.W.: Cosmetic assessment of breast-conserving surgery for primary breast cancer. Breast, 8 (4): 162-8, 1999.

26- Visser N.J., Damen T.H., Timman R., et al.: Surgical results, aesthetic outcome, and patient satisfaction after microsurgical autologous breast reconstruction following failed implant reconstruction. Plast. Reconstr. Surg., 126: 26-36, 2010.

27- Harris J.R., Levene M.B., Svensson G. and Hellman S.: Analysis of cosmetic results following primary radiation therapy for stages I and II carcinoma of the breast. Int. J. Radiat. Oncol. Biol. Phys., 5 (2): 257-26, 1979.

28- Al-Ghazal S.K. and Blamey R.W.: Cosmetic assessment of breast-conserving surgery for primary breast cancer. Breast, 8 (4): 162-8, 1999.

29- Al-Ghazal S.K., Fallowfield L. and Blamey R.W.: Patient evaluation of cosmetic outcome after conserving surgery for treatment of primary breast cancer. Eur. J. Surg. Oncol., 25 (4): 344-6, 1999.

30- Fahmy F. and Hemington-Gorse S.J.: The sitting, oblique, and supine marking technique for reduction mammaplasty and mastopexy. Plast. Reconstr. Surg., 117: 2145, 2006.

31- David T.J. and Winter R.M.: Familial absence of the pectoralis major, serratus anterior, and latissimus dorsi muscles. J. Med. Genet., 22: 390-2, 1985.3

32- Greydanus D.E., Matytsina L. and Gains M.: Breast disorders in children and adolescents. Prim. Care Clin. Office Pract., 33: 455-502, 2006.

33- Araco A., Gravante G., Araco F., Delogu D., Filingeri V. and Cervelli V.: Breast asymmetry: A heterogeneous condition. Plast. Reconstr. Surg., 118 (2): 563, 2006.

34- Ribeiro R.C., Saltz R., Mangles G.B. and Koch H.: Clinical and radiographic Poland syndrome classification: A proposal. Aesthet. Surg. J., 29: 494-504, 2009.

35- Brandberg Y., Arver B., Johansson H., et al.: Less correspondence between expectations before and cosmetic results after risk-reducing mastectomy in women who are mutation carriers: A prospective study. Eur. J. Surg. Oncol., 38: 38-43, 2012.

36- Gilmour A., Mackay I.R., Young D., et al.: The use of realtime digital video in the assessment of post-operative outcomes of breast reconstruction. J. Plast. Reconst r.Aesthet. Surg., 67: 1357-63, 2014.

37- Asplund O. and Nilsson B.: Interobserver variation and cosmetic result of submuscular breast reconstruction. Scand. J. Plast. Reconstr. Surg., 18: 215-20, 1984.

38- Brandberg Y., Malm M. and Blomqvist L.: A prospective and randomized study, "SVEA," comparing effects of three methods for delayed breast reconstruction on quality of life, patient-defined problem areas of life, and cosmetic result. Plast. Reconstr. Surg., 105: 66-74; discussion 75, 2000.
39- Cardoso M.J., Cardoso J., Santos A.C., et al.: Interobserver agreement and consensus over the esthetic evaluation of conservative treatment for breast cancer. Breast, 15: 527, 2006.

40- Charfare H., MacLatchie E. and Cordier C.: A comparison of different methods of assessing aesthetic outcome following breast-conserving surgery and factors influencing aesthetic outcome. Br. J. Med. Pract., 3 (1): 310-5, 2010.

41- Edsander-Nord A., Brandberg Y. and Wickman M.: Quality of life, patients' satisfaction, and aesthetic outcome after pedicled or free TRAM flap breast surgery. Plast. Reconstr. Surg., 107: 1142-53; discussion 1154, 2001.

42- Gui G.P., Tan S.M., Faliakou E.C., et al.: Immediate breast reconstruction using biodimensional anatomical permanent expander implants: A prospective analysis of outcome and patient satisfaction. Plast. Reconstr. Surg., 111: 12538; discussion 139, 2003.

43- Harris J.R., Levene M.B., Svensson G., et al.: Analysis of cosmetic results following primary radiation therapy for stages Iand II carcinoma of the breast. Int. J. Radiat. Oncol. Biol. Phys., 5: 257-61, 1979.

44- Mosahebi A., Ramakrishnan V., Gittos M., et al.: Aesthetic outcome of different techniques of reconstruction following nipple-areola- preserving envelope mastectomy with immediate reconstruction. Plast. Reconstr. Surg., 119: 796-803, 2007.

45- Sacchini V., Luini A., Tana S., et al.: Quantitative and qualitativecosmetic evaluation after conservative treatment for breast cancer. Eur. J. Cancer, 27: 1395-400, 1991.

46- Gahm J., Jurell G., Edsander-Nord A., et al.: Patient satisfaction with aesthetic outcome after bilateral prophylactic mastectomy and immediate reconstruction with implants. J. Plast. Reconstr. Aesthet. Surg., 63: 332-8, 2010.

47- Beadle G.F., Come S., Henderson I.C., Silver B., Hellman S. and Harris J.R.: The effect of adjuvant chemotherapy on the cosmetic results after primary radiation treatment for early stage breast cancer. Int. J. Radiat. Oncol. Biol. Phys., 10 (11): 2131-7, 1984.

48- Kaija H., Rauni S., Jorma I. and Matti H.: Consistency of patient-and doctor-assessed cosmetic outcome after conservative treatment of breast cancer. Breast Cancer Res. Treat., 45 (3): 225-8, Breast Cancer Res. Treat., (2012) 135: 629-637, 635, 123, 1997.

49- Abner A.L., Recht A., Vicini F.A., Silver B., Hayes D., Come S. and Harris J.R.: Cosmetic results after surgery, chemotherapy, and radiation therapy for early breast cancer. Int. J. Radiat. Oncol. Biol. Phys., 21 (2): 331-8, 1991.

50- Ash D.V., Benson E.A., Sainsbury J.R., Round C. and Head C.: Seven-year follow-up on 334 patients treated by breast conserving surgery and short course radical post-operative radiotherapy: A report of the Yorkshire Breast Cancer Group. Clin. Oncol. (R Coll Radiol), 7 (2): 93-6, 1995.

51- Gray J.R., McCormick B., Cox L. and Yahalom J.: Primary breast irradiation in large-breasted or heavy women: Analysis of cosmetic outcome. Int. J. Radiat. Oncol. Biol. Phys., 21 (2): 347-54, 1991. 
52- Lindsey I., Serpell J.W., Johnson W.R. and Rodger A.: Cosmesis following complete local excision of breast cancer. Aust. N. Z. J. Surg., 67 (7): 428-32, 1997.

53- Amichetti M., Busana L. and Caffo O.: Long-term cosmetic outcome and toxicity in patients treated with quadrantectomy and radiation therapy for early-stage breast cancer. Oncology, 52 (3): 177-81, 1995.

54- D'Aniello C., Grimaldi L., Barbato A., Bosi B. and Carli A.: Cosmetic results in 242 patients treated by conservative surgery for breast cancer. Scand J. Plast. Reconstr. Surg. Hand Surg., 33 (4): 419-22, 1999.

55- Davidson N.G., Khanna S., Windle R., Barrie W.W., Agrawal R.K. and Mitchell S.: Cosmetic results of early breast carcinoma treated with wide local excision, external beam radiotherapy and iridium-192 boost. J. R. Coll. Surg. Edinb., 35 (3): 175-7, 1990.

56- De La Rochefordiere A., Abner A.L., Silver B., Vicini F., Recht A. and Harris J.R.: Are cosmetic results following conservative surgery and radiation therapy for early breast cancer dependent on technique? Int. J. Radiat. Oncol. Biol. Phys., 23 (5): 925-31, 1992.

57- Sarin R., Dinshaw K.A., Shrivastava S.K., Sharma V. and Deore S.M.: Therapeutic factors influencing the cosmetic outcome and late complications in the conservative management of early breast cancer. Int. J. Radiat. Oncol. Biol. Phys., 27 (2): 285-92, 1993.

58- Dewar J.A., Benhamou S., Benhamou E., Arriagada R., Petit J.Y., Fontaine F. and Sarrazin D.: Cosmetic results following lumpectomy, axillary dissection and radiotherapy for small breastcancers. Radiother. Oncol., 12 (4): 27380, 1988.

59- Christie D., O'Brien M., Christie J., Kron T., Ferguson S., Hamilton C. and Denham J.: Comparison of methods of cosmetic assessment in breast conservation treatment. Breast, 5: 358-67, 1996.

60- Vrieling C., Collette L., Bartelink E., Borger J.H., Brenninkmeyer S.J., Horiot J.C., Pierart M., Poortmans P.M., Struikmans H., Van der Schueren E., Van Dongen J.A., Van Limbergen E. and Bartelink H.: Validation of the methods of cosmetic assessment after breast-conserving therapy in the EORTC "boost versus no boost" trial. EORTC radiotherapy and breast cancer cooperative groups. European Organization for research and treatment of cancer. Int. J. Radiat. Oncol. Biol. Phys., 45 (3): 667-76, 1999.

61- Sacchini V., Luini A., Tana S., Lozza L., Galimberti V., Merson M., Agresti R., Veronesi P. and Greco M.: Quantitative and qualitative cosmetic evaluation after conservative treatment for breast cancer. Eur. J. Cancer, 27 (11): 1395-400, 1991.

62- Al-Ghazal S.K., Blamey R.W., Stewart J. and Morgan A.A.: The cosmetic outcome in early breast cancer treated with breast conservation. Eur. J. Surg. Oncol., 25 (6): 566-70, 1999.

63- Sneeuw K.C., Aaronson N.K., Yarnold J.R., Broderick M., Regan J., Ross G. and Goddard A.: Cosmetic and functional outcomes of breast conserving treatment for early stage breast cancer. 1. Comparison of patients' ratings, observers' ratings, and objectiveassessments. Radiother. Oncol., 25 (3): 153-9, 1992.
64- Clarke D., Martinez A. and Cox R.S.: Analysis of cosmetic results and complications in patients with stage I and II breastcancer treated by biopsy and irradiation. Int. J. Radiat. Oncol. Biol. Phys., 9 (12): 1807-13, 1983.

65- Liljegren G., Holmberg L. and Westman G.: The cosmetic outcome in early breast cancer treated with sector resection with or without radiotherapy. Uppsala-Orebro Breast Cancer Study Group. Eur. J. Cancer, 29A (15): 2083-9, 1993.

66- Touboul E., Belkacemi Y., Lefranc J.P., Uzan S., Ozsahin M., Korbas D., Buffat L., Balosso J., Pene F., Blondon J., et al.: Early breast cancer: Influence of type of boost (electrons vs. iridium-192 implant) on local control and cosmesis after conservativesurgery and radiation therapy. Radiother. Oncol., 34 (2): 105-13, 1995.

67- Danoff B.F., Goodman R.L., Glick J.H., Haller D.G. and Pajak T.F.: The effect of adjuvant chemotherapy on cosmesis and complications in patients with breast cancer treated by definitive irradiation. Int. J. Radiat. Oncol. Biol. Phys., 9 (11): 1625-30, 1983.

68- Eadie C., Herd A. and Stallard S.: An investigation into digital imaging in assessing cosmetic outcome after breast surgery. J. Audiov. Media Med., 23 (1): 12-6, 2000.

69- Fagundes M.A., Fagundes H.M., Brito C.S., Fagundes M.H., Daudt A., Bruno L.A., Azevedo S.J. and Fagundes L.A.: Breast-conserving surgery and definitive radiation: A comparison between quadrantectomy and local excision with special focus on local-regional control and cosmesis. Int. J. Radiat. Oncol. Biol. Phys., 27 (3): 553-60, 1993.

70- Greco M., Sacchini V., Agresti A., Luini M.D.V., Farante G. and Raselli R.: Quadrantectomy is not a disfiguring operation for small breast cancer. Breast, 3 (1): 3-7, 1994.

71- Roelstraete A., Van Lancker M., De Schryver A. and Storme G.: Adjuvant radiation after conservative surgery for early breast cancer. Local control and cosmetic outcome. Am. J Clin. Oncol., 16 (4): 284-90, 1993.

72- Rose M.A., Olivotto I., Cady B., Koufman C., Osteen R., Silver B., Recht A. and Harris J.R.: Conservative surgery and radiation therapy for early breast cancer. Long-term cosmetic results. Arch. Surg., 124 (2): 153-7, 1989.

73- Cetintas S.K., Ozkan L., Kurt M., Saran A., Tasdelen I., Tolunay S., Topal U. and Engin K.: Factors influencing cosmetic results after breast conserving management (Turkish experience). Breast, 11 (1): 72-80, doi:10.1054/ brst.2001.0372, 2002.

74- Gilmour A., Mackay I.R., Young D., et al.: The use of realtime digital video in the assessment of post-operative outcomes of breast reconstruction. J. Plast. Reconstr. Aesthet. Surg., 67: 1357-63, 2014.

75- Potter S., Harcourt D., Cawthorn S., et al.: Assessment of cosmesis after breast reconstruction surgery: A systematic review. Ann. Surg. Oncol., 18: 813-23, 2011.

76- Cobben J.W., Robinson P.H., Van Essen A.J., Van der Wiel H.L. and Ten Kate L.P.: Poland syndrome in mother and daughter. Am. J. Med. Genet., 33: 519, 1984.

77- Darian V.B., Argenta L.C. and Pasyk K.A.: Familial Poland's syndrome. Ann. Plast. Surg., 23: 531, 1989.

78- Blugerman G., Amar R., Schavelzon D., Pelosi II M.A., Soto J.A., Chomyszyn A., Podda M., Markowsky A.V., D'Angelo J.A. and Moreno R.: Advanced lipotransfer 
techniques. In: Serdev N (ed), Advanced techniques in liposuction and fat transfer. ISBN: 978-953-307-668-3. doi: 10.5772/24745. Available at http://www.intechopen. com books advanced techniques in liposuction and fat transfer advanced lipotransfer techniques, 2011

79- Ozgur F., Gokalan I., Mavili E., Erk Y. and Kecik A.: Reconstruction of post-burn breast deformities. Burns, 18: 504-9, 1992.

80- E.M. Wolfswinkel, V. Lemaine, W.M. Weathers, C.J. Chike Obi, A.S. Xue and L. Heller: "Hyperplastic breast anomalies in the female adolescent breast," Seminars in Plastic Surgery, Vol. 27, No. 1, pp. 49-55, 2013.

82- R.E. Austin, F. Lista and J. Ahmad: "Management of recurrent or persistent macromastia," Clinics in Plastic Surgery, Vol. 43, No. 2, pp. 383-93, 2016.

83- L.S. Neinstein: "Breast disease in adolescents and young women," Pediatric Clinics of North America, Vol. 46, No. 3, pp. 607-29, 1999.

84- K. Allah, H. Kossoko, V. Assi Dje Bi Dj É., S.Y. éo and M. Richard Kadio: "Gigantomastie juvenile: Á propos de deux cas traités' par la plastie mammaire de reduction avec greffe de la plaqué areolomamelonnaire," Journal de Gynecologie Obst. étrique et ' Biologie de la Reproduction, Vol. 40, No. 4, pp. 363-6, 2011.

85- K. Demir, T. Unuvar, S. Eren, A. Abaci and E. Bober: "Tamoxifen as first-line treatment in a premenarchal girl with juvenile breast hypertrophy," Journal of Pediatric and Adolescent Gynecology, Vol. 23, No. 5, pp. e133e136, 2010.

86- F. Gentimi, A.C. Loupatatzi, K.P. Euthimoglou, et al.: "Juvenile gigantomastia in a 12 -year-old girl: A case report," Aesthetic Plastic Surgery, Vol. 35, No. 3, pp. 414-7, 2011.

87- A. Gozü, F.N. Yögun, Z.Ǒzsoy, A. Özdemir, G. Özgürhan, and S. Tuzlali: "Juvenile breast hypertrophy," Journal of Breast Health, Vol. 6, No. 3, pp. 122-4, 2010.

88- E. Menekse, S. Onel, F. Karateke, et al.: "Virginal breast hypertrophy and symptomatic treatment: A case report," Journal of Breast Health, Vol. 10, No. 2, pp. 122-4, 2014.

89- G. Karaguzel, S. Bilen, N. Karac̈ąl, K. Yıldız, and M. Livaoglu: "Virginal breast hypertrophy: Different presentations of 2 cases and the role of tamoxifen as an adjuvant therapy," Journal of Pediatric and Adolescent Gynecology, Vol. 29, No. 5, pp. e71-e74, 2016.

90- T. Ewies, A. Abbas, S. Amr and A.E. Arini: "Unilateral virginal breast hypertrophy in an 11-year-old girl," Breast Journal, Vol. 19, No. 2, pp. 202-4, 2013.

91- Efrat M., Mogilner J.G., Iujtman M., Eldemberg D., Kunin J. and Eldar S.: Neonatal mastitis: Diagnosis and treatment. Isr. J. Med. Sci., 31: 558-60 [23], 1995.

92- Illouz Y.G. and Sterodimas A.: Autologous fat transplantation to the breast: A personal technique with 25 years of experience. Aesthetic Plast. Surg., 33 (5): 706-15, 2009.

93- Kamal R.M., Hamed S.H. and Salem D.S.: Classification of inflammatory breast disorders and step by step diagnosis. Breast J., 15 (4): 367-80, 2009.

94- Ribeiro L., Accorsi A., Buss A. and Pessoa M.C.M.: Short scar correction of the tuberous breast. Clin. Plast. Surg., 29: 423-31, 2002.
95- Christie D., O'Brien M., Christie J., et al.: A comparison of methods of cosmetic assessment in breast conservation treatment. Breast, 5: 358-67, 1996.

96- Vrieling C., Collette L., Fourquet A., et al.: The influence of patient, tumor and treatment factors on the cosmetic results after breast-conserving therapy in the EORTC 'boost versus no boost' trial. EORTC Radiotherapy and Breast Cancer Cooperative Groups. Radiother. Oncol., 55 (3): 219-32, 2000.

97- Cochrane R.A., Valasiadou P., Wilson A.R., et al.: Cosmesis and satisfaction after breast-conserving surgery correlates with the percentage of breast volume excised. Br. J. Surg., 90 (12): 1505-9, 2003.

98- Pezner R.D., Patterson M.P., Hill L.R., et al.: Breast retraction assessment: An objective evaluation of cosmetic results of patients treated conservatively for breast cancer. Int. J. Radiat. Oncol. Biol. Phys., 11 (3): 575-8, 1985.

99- Van Limbergen E., van der Schueren E. and Van Tongelen K.: Cosmetic evaluation of breast conserving treatment for mammary cancer. 1. Proposal of a quantitative scoring system. Radiother. Oncol., 16 (3): 159-67, 1989.

100- Triedman S.A., Osteen R. and Harris J.R.: Factors influencing cosmetic outcome of conservative surgery and radiotherapy for breast cancer. Surg. Clin. N. Am., 70 (4): 901-16, 1990.

101- Krishnan L., Stanton A.L., Collins C.A., et al.: Form or function? Part 2. Objective cosmetic and functional correlates of quality of life in women treated with breastconserving surgical procedures and radiotherapy. Cancer, 91 (12): 2282-7, 2011.

102- Sacchini V., Luini A., Tana S., et al.: Quantitative and qualitative cosmetic evaluation after conservative treatment for breast cancer. Eur. J. Cancer, 27 (11): 1395400, 1991.

103- Al-Ghazal S.K., Blamey R.W., Stewart J. and Morgan A.A.: The cosmetic outcome in early breast cancer treated with breast conservation. Eur. J. Surg. Oncol., 25 (6): 566-70, 1999.

104- Barnea Y., Inbal A., Barsuk D., et al.: Oncoplastic reduction using the vertical scar superior-medial pedicle pattern technique for immediate partial breast reconstruction. Can. J. Surg., 57: E134-E140, 2014.

105- Haloua M.H., Krekel N. and Winters Henri A.H.: A systematic review of oncoplastic breast-conserving surgery: Current weaknesses and future prospects. Ann. Surg., 257: 609-20, 2013.

106- Bong J., Parker J., Clapper R. and Dooley W.: Clinical series of oncoplastic mastopexy to optimize cosmesis of large-volume resections for breast conservation. Ann. Surg. Oncol., 17: 3247-51, 2010.

107- Veiga D.F., Veiga-Filho J., Ribeiro L.M., et al.: Qualityof-life and self-esteem outcomes after oncoplastic breastconserving surgery. Plast. Reconstr. Surg., 125: 811-7, 2010.

108- Malka I., Villet R., Fitoussi A., et al.: Oncoplastic conservative treatment for breast cancer (part 4): Techniques for inner quadrants. J. Visc. Surg., 147: e373e376, 2010.

109- Malka I., Villet R., Fitoussi A., et al.: Oncoplastic conservative treatment for breast cancer (part 3): Tech- 
niques for the upper quadrants. J. Visc. Surg., 147: e365e372, 2010.

110- Malka I., Villet R., Fitoussi A., et al.: Oncoplastic conservative treatment for breast cancer (part 1): Generalities and techniques for the external quadrants. J. Visc. Surg., 147: e233-e237, 2010.

111- Malka I., Villet R., Fitoussi A., et al.: Oncoplastic conservative treatment for breast cancer (part 2): Techniques for the inferior quadrants. J. Visc. Surg., 147: e305-e315, 2010.

112- Yang J.D., Lee J.D. and Cho Y.K.: Surgical techniques for personalized oncoplastic surgery in breast cancer patients with small-to moderate-sized breasts (part 1): Volume displacement. J. Breast Cancer, 15 (1): 1-6, 2012.

113- Dal Cin A., Knight C., Whelan K.F., et al.: Bilateral reduction mammoplasty following breast cancer: A casecontrol study. Can J. Plast. Surg., 20: e6-e9, 2012.

114- Weichman K.E., Urbinelli L., Disa J.J., et al.: Breast reduction in patients with prior breast irradiation: Outcomes using a central mound technique. Plast. Reconstr. Surg., 135 (5): 1276-82, 2015.

115- Spear S.L., Burke J.B., Forman D., et al.: Experience with reduction mammaplasty following breast conservation surgery and radiation therapy. Plast. Reconstr. Surg., 102: 1913-6, 1998.
116- Spear S.L., Rao S.S., Patel K.M. and Nahabedian M.Y.: Reduction mammaplasty and mastopexy in previously irradiated breasts. Aesthet. Surg. J., 34: 74-8, 2014.

117- Christiansen D., Kazmier F.R. and Puckett C.L.: Safety and aesthetic improvement using the omega pattern reduction mammoplasty after breast conservation surgery and radiation therapy. Plast. Reconstr. Surg., 121: 37480, 2008.

118- Handel N., Lewinsky B. and Waisman J.R.: Reduction mammaplasty following radiation therapy for breast cancer. Plast. Reconstr. Surg., 89: 953-5, 1992.

119- Patel K.M., Hannan C.M., Gatti M.E. and Nahabedian M.Y.: A head-to-head comparison of quality of life and aesthetic outcomes following immediate, stagedimmediate, and delayed oncoplastic reduction mammaplasty. Plast. Reconstr. Surg., 127 (6): 2167-75, 2011.

120- Chin M.S., Brooks G.S., Stueber K., et al.: Asymmetry correction in the irradiated breast: Outcomes of reduction mammaplasty and mastopexy after breast-conserving therapy. Aesthet. Surg. J., 29: 106-12, 2009.

121- Barnea Y., Bracha G., Arad E., Gur E. and Inbal A.: Breast Reduction and Mastopexy for Repair of Asymmetry After BreastConservation Therapy: Lessons Learned. Aesthetic Plast. Surg., Jun., 43 (3): 600-7, 2019. 